Prepared in cooperation with the National Park Service and the Bureau of Reclamation

\title{
Assessment of Polycyclic Aromatic Hydrocarbon Concentrations in Southern Lake Powell, Glen Canyon National Recreation Area, Arizona and Utah, 2016-17
}

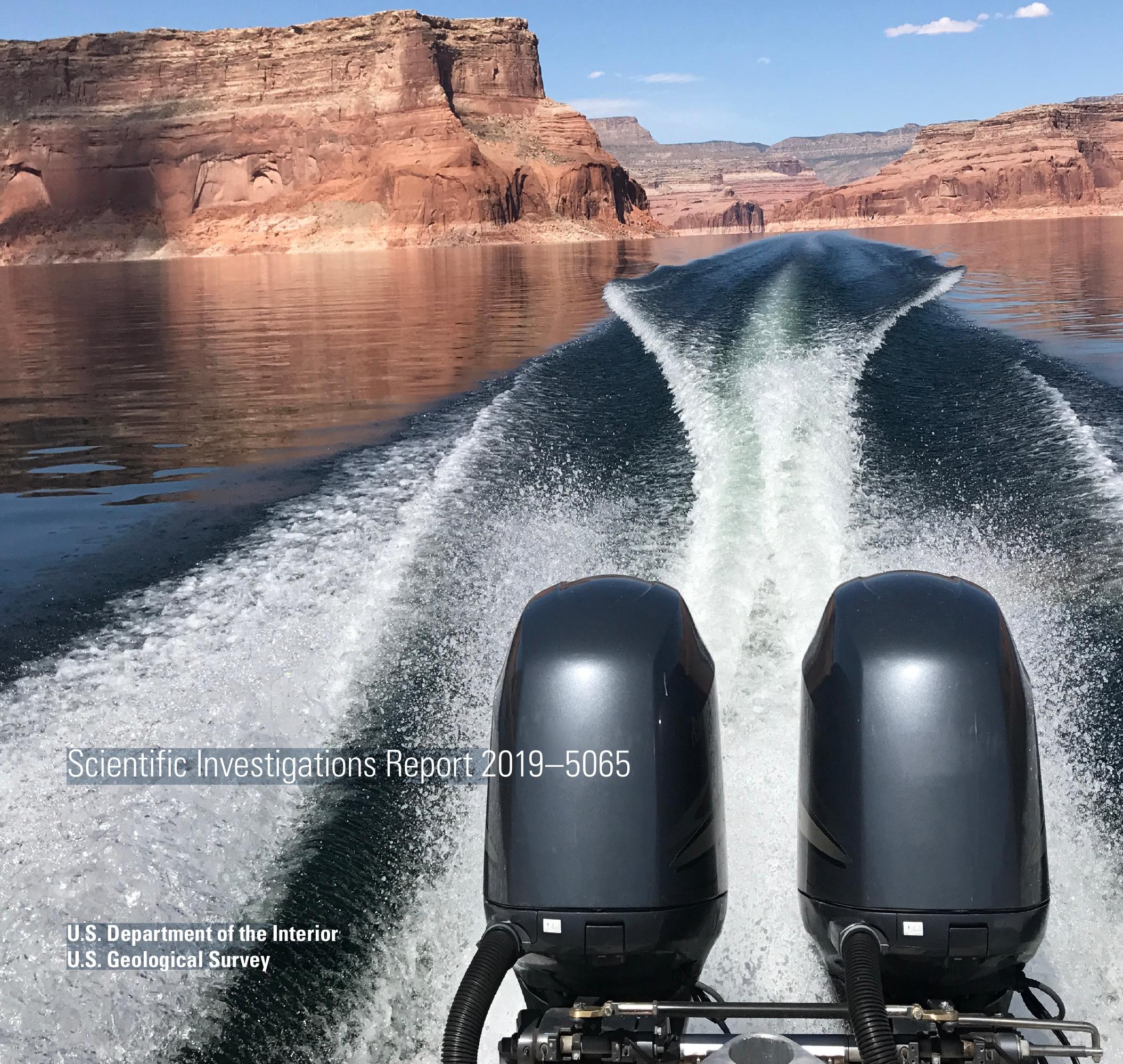


Cover. Photograph of twin 4-stroke outboard motors cutting through the calm and glassy waters of Lake Powell, Ariz. and Utah. U.S. Geological Survey photograph by Jamie Macy. 


\section{Assessment of Polycyclic Aromatic Hydrocarbon Concentrations in Southern Lake Powell, Glen Canyon National Recreation Area, Arizona and Utah, 2016-17}

By Alissa L. Coes, Nicholas V. Paretti, David A. Alvarez, and Jamie P. Macy

Prepared in cooperation with the National Park Service and the Bureau of Reclamation

Scientific Investigations Report 2019-5065 


\title{
U.S. Department of the Interior \\ DAVID BERNHARDT, Secretary
}

\author{
U.S. Geological Survey \\ James F. Reilly II, Director
}

U.S. Geological Survey, Reston, Virginia: 2019

For more information on the USGS - the Federal source for science about the Earth, its natural and living resources, natural hazards, and the environment-visit https://www.usgs.gov or call 1-888-ASK-USGS.

For an overview of USGS information products, including maps, imagery, and publications,

visit https://store.usgs.gov.

Any use of trade, firm, or product names is for descriptive purposes only and does not imply endorsement by the U.S. Government.

Although this information product, for the most part, is in the public domain, it also may contain copyrighted materials as noted in the text. Permission to reproduce copyrighted items must be secured from the copyright owner.

Suggested citation:

Coes, A.L., Paretti, N.V., Alvarez, D.A., and Macy, J.P., 2019, Assessment of polycyclic aromatic hydrocarbon concentrations in southern Lake Powell, Glen Canyon National Recreation Area, Arizona and Utah, 2016-17: U.S. Geological Survey Scientific Investigations Report 2019-5065, 26 p., https://doi.org/10.3133/sir20195065.

ISSN 2328-0328 (online) 


\section{Contents}

Abstract

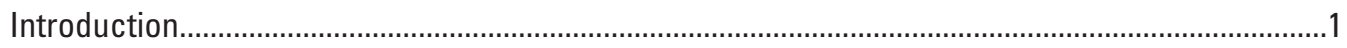

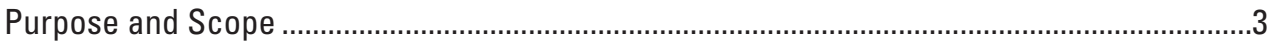

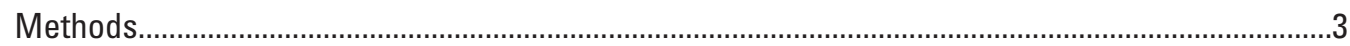

Semipermeable Membrane Device Construction ...................................................................

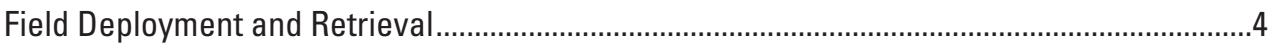

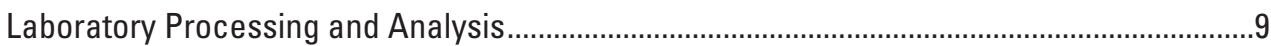

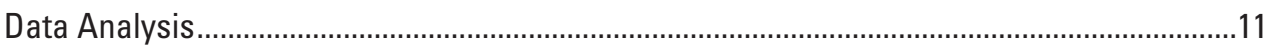

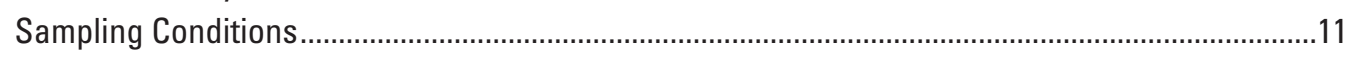

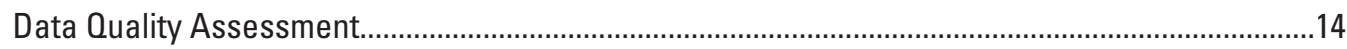

Polycyclic Aromatic Hydrocarbon Concentrations ......................................................................14

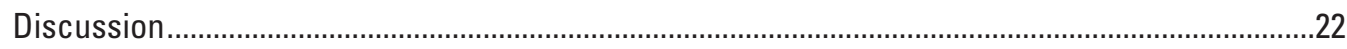

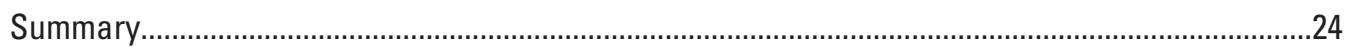

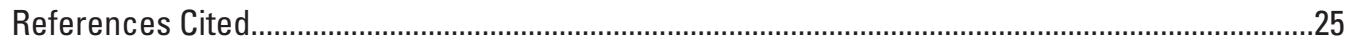

\section{Figures}

1. Map of Glen Canyon National Recreation Area, Lake Powell, and monitoring

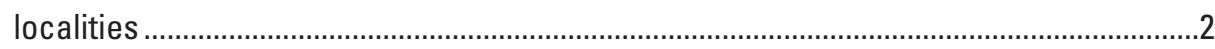

2. Graphs of the thermocline at semipermeable membrane device deployment and retrieval .................................................................................................................

3. Water surface elevation graphs of Lake Powell from 2016-17 and from 1980-2017

4. Graphs of monthly boat use in Lake Powell in terms of boat rentals and occupied boat moorings at Wahweap Marina, 2010-17.

5. Diagram of polycyclic aromatic hydrocarbon concentrations at Lake Powell monitoring sites, 2016-17.

6. Graph showing number of polycyclic aromatic hydrocarbon detections at Lake Powell monitoring sites, 2016-17

7. Graph showing total number of polycyclic aromatic hydrocarbons detected at Lake Powell monitoring sites ...............................................................................................16

8. Graphs illustrating the total number of polycyclic aromatic hydrocarbons detected at Lake Powell monitoring sites during each sampling event, 2016-17

9. Diagram showing nonmetric multidimensional scaling (NMDS) ordination plot of polycyclic aromatic hydrocarbon concentrations.

10. Boxplot graphs showing spring versus summer concentrations of polycyclic aromatic hydrocarbons

11. Diagram of polycyclic aromatic hydrocarbon concentrations at Lake Powell monitoring sites, summer 2010, summer 2016, and summer 2017.

12. Graph illustrating median rank of polycyclic aromatic hydrocarbon concentrations at Lake Powell monitoring sites, summer 2010, summer 2016, and summer 2017...............22

13. Diagram of a non-metric multidimensional scaling ordination for polycyclic aromatic hydrocarbon concentrations at each site during each summer sampling event...........23 


\section{Tables}

1. Description of sampled sites, deployment depths, and quality-control data ....................9

2. Method detection and method quantitation limits ............................................................10

3. Polycyclic aromatic hydrocarbons with average recoveries less than 75 percent........14

4. Linkage trees and similarity profile multivariate analysis results .....................................19

5. Method detection limits and number of detections of summer 2010, summer 2016, and summer 2017 samples

6. National recommended human health criteria and Arizona surface-water quality standards for polycyclic aromatic hydrocarbons

\section{Conversion Factors}

U.S. customary units to International System of Units

\begin{tabular}{|c|c|c|}
\hline Multiply & By & To obtain \\
\hline \multicolumn{3}{|c|}{ Length } \\
\hline foot $(\mathrm{ft})$ & 0.3048 & meter (m) \\
\hline mile (mi) & 1.609 & kilometer (km) \\
\hline \multicolumn{3}{|c|}{ Volume } \\
\hline gallon (gal) & 3.785 & liter (L) \\
\hline
\end{tabular}

Temperature in degrees Celsius $\left({ }^{\circ} \mathrm{C}\right)$ may be converted to degrees Fahrenheit $\left({ }^{\circ} \mathrm{F}\right)$ as follows: ${ }^{\circ} \mathrm{F}=\left(1.8 \times{ }^{\circ} \mathrm{C}\right)+32$. 


\section{Datum}

Elevation, as used in this report, refers to distance above sea level.

\section{Supplemental Information}

Concentrations of chemical constituents in water are given in picograms per liter (pg/L).

\section{Abbreviations}

$\begin{array}{ll}\text { ADEQ } & \text { Arizona Department of Environmental Quality } \\ \text { ANOSIM } & \text { Analysis of Similarities } \\ \text { CERC } & \text { Columbia Environmental Research Center } \\ \text { MDL } & \text { method detection limit } \\ \text { MQL } & \text { method quantitation limit } \\ \text { NMDS } & \text { non-metric multidimensional scaling } \\ \text { NPS } & \text { National Park Service } \\ \text { PAH } & \text { polycyclic aromatic hydrocarbon } \\ \text { PRC } & \text { performance reference compound } \\ \text { QC } & \text { quality control } \\ \text { ROS } & \text { regression on order statistics } \\ \text { RPD } & \text { relative percent difference } \\ \text { SEC } & \text { size exclusion chromatography } \\ \text { SPMD } & \text { semipermeable membrane device } \\ \text { USGS } & \text { U.S. Geological Survey }\end{array}$





\title{
Assessment of Polycyclic Aromatic Hydrocarbon Concentrations in Southern Lake Powell, Glen Canyon National Recreation Area, Arizona and Utah, 2016-17
}

\author{
By Alissa L. Coes, Nicholas V. Paretti, David A. Alvarez, and Jamie P. Macy
}

\section{Abstract}

Polycyclic aromatic hydrocarbon contamination related to boat use is one of the most important water-quality issues affecting Lake Powell. High concentrations of polycyclic aromatic hydrocarbons in water are common around marinas and other areas with extensive motorboat activity because of releases of uncombusted or partially combusted oil and gasoline from boat engines. The fate of these compounds in Lake Powell is of serious environmental concern because of their toxicity and carcinogenicity and their moderate persistence once they enter the aquatic ecosystem. In 2016-17, the U.S. Geological Survey (USGS) assessed the presence and concentrations of polycyclic aromatic hydrocarbons in Lake Powell at seven sites where concentrations have historically been elevated, and one site where concentrations have historically been relatively low. Semipermeable membrane devices were used to collect samples which represent time-weighted averages of polycyclic aromatic hydrocarbon concentrations in water over one-month deployment periods. Samples were collected from the epilimnion of the lake at each of the eight sampling sites during two periods of relatively high boat use (summer), and one period of relatively low boat use (spring). Twenty-eight out of 33 polycyclic aromatic hydrocarbons analyzed were detected in Lake Powell during the three sampling events. During the two summer sampling events, concentrations were generally higher, and more compounds were detected, than during the spring sampling event. Twenty-two of the polycyclic aromatic hydrocarbons analyzed in 2016-17 had previously been analyzed by the USGS in the summer of 2010 at the same 8 sites using the same collection method. Eleven of 22 compounds were detected in the summer 2010, summer 2016, and summer 2017 sampling events, and 1 was detected in the summer 2010 and summer 2017 samplings, but not in the summer 2016 sampling event. During both the current and previous sampling events, concentrations were generally higher, and more compounds were detected, at the high-use marina sites located most downstream on the lake. The consistent presence of a wide range of polycyclic aromatic hydrocarbons in the water of Lake Powell indicates chronic and (or) recent anthropogenic sources of contamination. The results from this study will provide the National Park Service with information necessary to determine if the current regulations on emission standards for personal watercraft used on Lake Powell are effective in lowering polycyclic aromatic hydrocarbon concentrations in the lake.

\section{Introduction}

Glen Canyon National Recreation Area is in northern Arizona and southeastern Utah within the Colorado Plateau physiographic province and includes Lake Powell (fig. 1). Glen Canyon National Recreation Area was established on October 27, 1972, to "...provide for public outdoor recreation use and enjoyment of Lake Powell and lands adjacent thereto in the States of Arizona and Utah and to preserve the scenic, scientific, and historic features contributing to the public enjoyment of the area..." (16 U.S. Code $\$ 460 d d 1972$; Public Law 92-593).

There are many types of recreational activities at Glen Canyon National Recreation Area including camping, backcountry hiking, boating, fishing, and lodging at the park. Since 1998, the number of recreation visitors to Glen Canyon National Recreation Area has ranged from 1.8 to 4.6 million people. In 2016 and 2017, 3.2 and 4.6 million people visited Glen Canyon National Recreation Area for recreational purposes, respectively (National Park Service, 2018). Recreational boating on Lake Powell is by far the most popular activity in Glen Canyon National Recreation Area, and includes the use of houseboats, power boats, and personal watercraft. There are five marinas located within Glen Canyon National Recreation Area. Contamination related to emissions from boat engines is one of the most significant water-quality issues affecting Lake Powell. Most of the visitors to Glen Canyon National Recreation Area engage in boating activities and come into direct contact with the water in Lake Powell. In addition, Lake Powell is a water source for public and agricultural consumption and is critical for the wildlife at Glen Canyon National Recreation Area. 


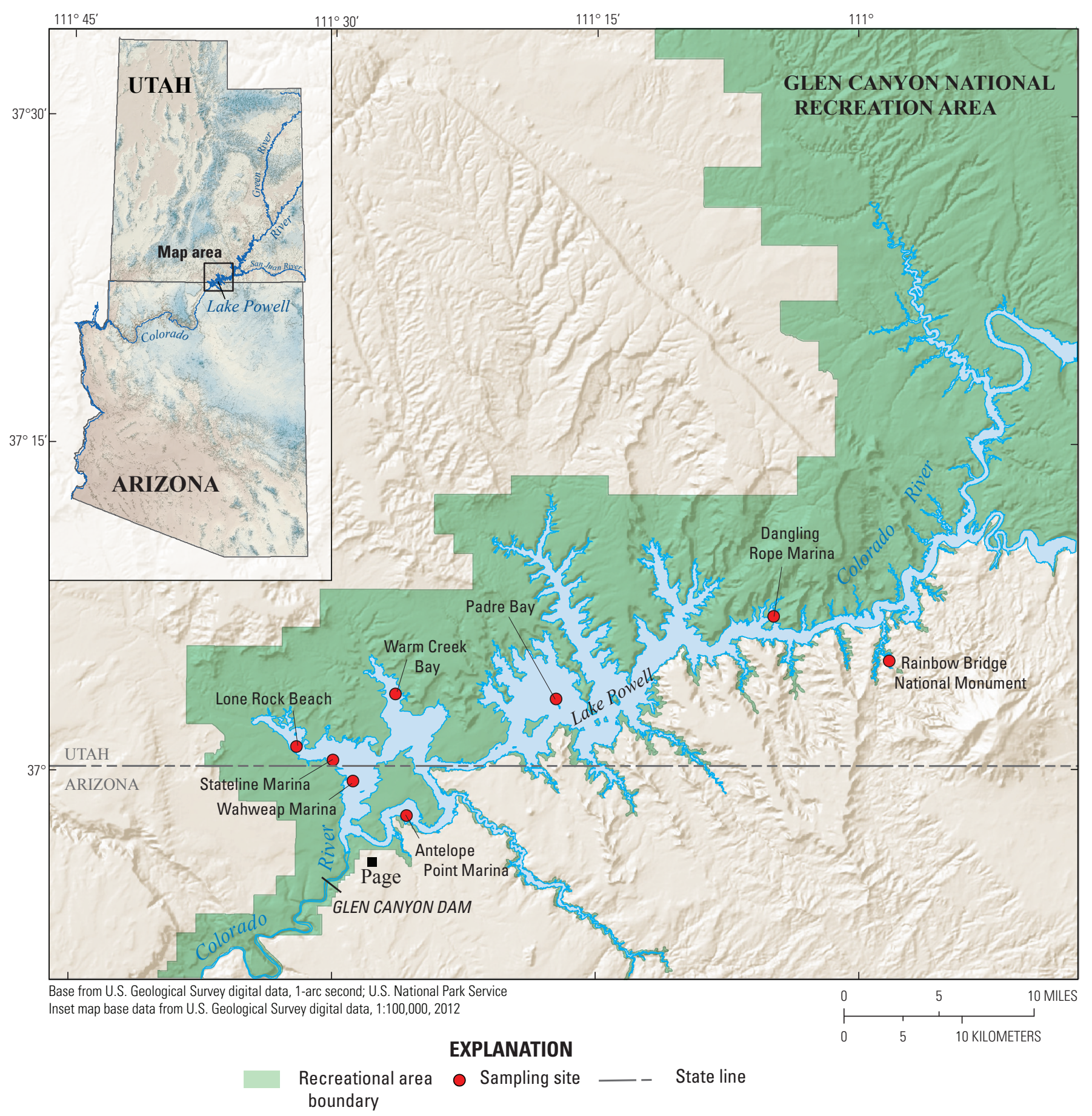

Figure 1. Map of Glen Canyon National Recreation Area, Lake Powell, and monitoring localities.

Polycyclic aromatic hydrocarbons (PAHs) can be released into the water and air through uncombusted or partially combusted releases of oil and gasoline from boat engines. The introduction of PAHs to the environment is of concern because of their known toxicity and carcinogenicity (Abrajano and others, 2003). Once in the aquatic system, the fate of PAHs is dependent on the structure and physical properties of each individual PAH. PAHs have low water solubilities, tending to partition out of the dissolved phase into the solid phase, and preferentially bind to organic matter on suspended particles and sediment (Abrajano and others, 2003). Despite their low solubilities, an important destruction pathway of PAHs in the aquatic environment is biodegradation in their dissolved phase (Abrajano and others, 2003). Additionally, many PAHs are hydrophobic, leading to bioaccumulation factors in aquatic organisms (U.S. National Library of Medicine, 2017). 
The lighter aliphatic and aromatic PAHs tend to float on the aqueous surface and volatilize into the atmosphere (Abrajano and others, 2003). Some PAHs are susceptible to degradation upon exposure to ultraviolet radiation from sunlight (photolysis) and can degrade in minutes to hours (Huckins and others, 2006). Photolysis of PAHs has its own risks as many of the degradation products can have greater levels of toxicity than the parent PAHs (Marzooghi and Di Toro, 2017). PAH half-lives in natural open-water systems is generally on the order of hours to days to months, depending on environmental conditions and the specific PAH under consideration (U.S. National Library of Medicine, 2017). Because of the hydrophobic nature of PAHs, and their susceptibility to degradation and volatilization, the presence of PAHs in water generally indicates chronic and (or) recent contamination from anthropogenic sources.

In an effort to reduce PAH concentrations at Glen Canyon National Recreation Area, the National Park Service (NPS) adopted special regulations in 2003 to manage the use of personal watercraft on Lake Powell, as described in the Record of Decision signed on June 27, 2003, for the final Environmental Impact Statement concerning the use of personal watercraft on waters of Glen Canyon National Recreation Area (National Park Service, 2003). The special regulations defined personal watercraft emission standards, but there was a 10-year delay of implementing the standards to allow personal watercraft owners time to transition. Since December 31, 2012, the new regulations have been included in the Code of Federal Regulations, which states that no one may operate a personal watercraft that does not meet 2006 emission standards set by the Environmental Protection Agency for the manufacturing of two-stroke engines (36 CFR $\$ 7.70$ (e)(3)). Also included as part of the Record of Decision, NPS is required to sample and monitor for PAH concentrations in Lake Powell.

In 2004, at the request of the NPS, the U.S. Geological Survey (USGS) prepared a plan for monitoring PAH concentrations in Lake Powell (National Park Service, 2004). As part of the monitoring plan, the USGS and NPS established 20 sentinel monitoring sites to provide consistent sampling locations to monitor changes in water and sediment quality in Lake Powell (Hart and others, 2012). During 2004 to 2006, the USGS collected discrete water samples at these sites in cooperation with the NPS for analysis by the Environmental Protection Agency method 1664, revision B (U.S. Environmental Protection Agency, 2010). Oil and grease products (n-hexane extractable material) were detected in water at 9 of the 20 sites, and total petroleum hydrocarbons (nonpolar material) were detected in water at all 20 of the sites (Hart and others, 2012; U.S. Environmental Protection Agency, 2010).

In 2010-11, the USGS and NPS again partnered to collect discrete sediment samples and composite water samples at the Lake Powell sentinel monitoring sites (Schonauer and others, 2013). In Schonauer and others (2013), the time-weighted average concentrations of PAHs in water were determined using semipermeable membrane device (SPMD) passive samplers. PAHs were detected most frequently at sites in the southern part of Lake Powell, where visitation and boat use are high. The most commonly detected compounds in water were fluoranthene, chrysene, 4,5-methylenephenanthrene, and 1-methylphenanthrene, which were detected at 94 percent, 83 percent, 78 percent, and 72 percent of the sites, respectively. The most commonly detected compounds in sediment were 2,6-dimethylnaphthaline and 1,6-dimethylnaphthaline, which were detected at 65 percent and 55 percent of the sites, respectively.

The previous studies (Hart and others, 2012; Schonauer and others, 2013) have provided baseline information on $\mathrm{PAH}$ concentrations in Lake Powell that the NPS is using to make management decisions about the use of personal watercraft within Glen Canyon National Recreation Area. These studies have also identified sites at Lake Powell where additional monitoring is necessary to determine if PAH concentrations in water are increasing or decreasing over time. Additional PAH sampling on Lake Powell is critical to NPS in order to both determine the effectiveness of the newly enacted management policies, and to fully understand the relation between boating and PAH concentrations in water.

\section{Purpose and Scope}

This study reports PAH detections and concentrations at eight of the sentinel monitoring sites sampled in 2016 and 2017 previously established by Hart and others (2012). In addition, the 2016-17 PAH detections and concentrations are compared to previously reported PAH detections and concentrations collected in 2010 at the eight monitoring sites (Schonauer and others, 2013). Sampling occurred during periods of both high boat use and low boat use. The results from this study provides Glen Canyon National Recreation Area with the necessary information to determine if the current policies concerning personal watercraft on Lake Powell are effective management techniques for lowering PAH concentrations.

\section{Methods}

In-situ passive samplers, SPMDs, were used in this study to collect samples that represent time-weighted averages of concentrations in water over the deployment periods. The theory and use of SPMDs are described in detail in Huckins and others (2006) and Alvarez (2010), whereas a general overview is given here. SPMD samplers consist of a neutral lipid, ultra-high-purity triolein, encased in a thin-walled layflat polyethylene membrane tube (Huckins and others, 2006). The hydrophobic nature of PAHs allows these compounds to partition out of the water and into the membrane and lipid of the SPMD. SPMDs continually sample the surrounding water over the period of deployment. The volume of water sampled during a SPMD deployment is a function of the sampling rate for a particular compound and the sampling duration. The estimation of the time-weighted average concentration 
of chemicals in the water is determined from the concentration of the chemicals accumulated in the SPMD and uptake models which take into account the site-specific environmental variables (Alvarez, 2010). The integrative nature of SPMDs accumulates compounds and increases the probability that sampled concentrations will be above analytical method detection limits.

\section{Semipermeable Membrane Device Construction}

The SPMDs were prepared at the USGS Columbia Environmental Research Center (CERC) and consisted of 91 centimeter-long thin-walled, layflat polyethylene membrane tubes containing 1 milliliter of ultra-high-purity triolein. Each SPMD was spiked in the laboratory prior to deployment with fluorene- $d_{10}$, phenanthrene- $d_{10}$, and pyrene- $d_{10}$ to serve as performance reference compounds (PRCs) to understand potential low bias caused by environmental interference of SPMD sampling rates. In addition, the photolysis marker dibenz $[a, h]$ anthracene- $d_{14}$ was spiked into each SPMD during construction to understand potential low bias caused by PAH degradation upon exposure to sunlight. For deployment at each site, two SPMDs were placed inside of stainless-steel deployment canisters. The deployment canisters were then sealed inside of solvent-rinsed, air-tight metal cans and kept chilled below 4 degrees Celsius until deployment.

Additional SPMDs were constructed concurrently with each group of field SPMDs for quality-control (QC) purposes. With each group of field SPMDs, two SPMDs were constructed and stored at CERC in air-tight, solvent-rinsed containers and kept below -20 degrees Celsius to serve as fabrication blanks. Also, with each group of field SPMDs, additional SPMDs were constructed for use as field blanks and for use as field replicates. Each field blank SPMD consisted of one SPMD sealed inside of a solvent-rinsed air-tight metal can, and each field replicate SPMD consisted of an additional two SPMDs placed inside of a field SPMD deployment canister. Fabrication blanks, field blanks, and field replicates were all spiked with the same PRCs and photolysis markers as the field SPMDs. SPMDs for use as field blanks and field replicates were kept chilled below 4 degrees Celsius until deployment.

\section{Field Deployment and Retrieval}

SPMD samplers were deployed at seven sites with the greatest number of PAH detections in water from Schonauer and others (2013) (Antelope Point Marina, Dangling Rope Marina, Lone Rock Beach, Rainbow Bridge National Monument, Stateline Marina Boat Docks (locally known as Stateline Marina), Wahweap Marina, and Warm Creek Bay;

fig. 1). One additional site with a relatively lower number of PAH detections from Schonauer and others (2013), Padre Bay, was resampled as a control site (fig. 1). Each of the sampled sites is described in detail by Hart and others (2012). Antelope Point Marina, Wahweap Marina, and Dangling Rope Marina have boat fuel docks, though Antelope Point Marina and Wahweap Marina are higher use than Dangling Rope Marina because of their proximity to Page, Ariz., and their boat launching, mooring, and rental services (Hart and others, 2012). Stateline Marina does not have a boat fuel dock but does have boat launching and mooring services. Lone Rock Beach, Rainbow Bridge National Monument, and Warm Creek Bay are in side canyons, beaches, and bays with relatively high boat traffic (Hart and others, 2012).

SPMD samplers were deployed according to field methods outlined in Alvarez (2010). Samplers were deployed three times at each of the eight sites; two of the SPMD deployments were during periods of high boat use (June 21, 2016 through July 19, 2016 [summer 2016] and June 29, 2017 through July 26, 2017 [summer 2017]) and one deployment was during a period of relatively lower boat use (April 18, 2017 through May 16, 2017 [spring 2017]). Over the course of the deployments, four SPMD samplers were either stolen or damaged, and samples from those sites and periods were therefore lost. Data from these samples could not be included in the data analysis (summer 2017 sample from Lone Rock Beach; summer 2016, spring 2017, and summer 2017 samples from Padre Bay).

During the summer, PAHs potentially associated with increased boat traffic at Lake Powell would most likely be in the upper water column, because PAHs associated with fuels will float on the water surface. Therefore, SPMD samplers were deployed in the water column within the epilimnion at depths ranging from 5 to 17 feet below the water surface (fig. 2). The thermocline was measured during deployment and retrieval using a Sea-Bird Electronics, Inc., model SBE25 conductivity, temperature, and depth (CTD) profiler to monitor if the SPMDs remained within the epilimnion during the deployment period. All sensors of the SBE25 CTD were calibrated by the manufacturer in April 2016 and calibration coefficients were updated in the Sea-Bird Electronics software following calibration. In addition, Onset Computer Corporation TidbiT version 2 temperature loggers were deployed with each SPMD to monitor if there were any significant temperature changes during the deployment period (Mayo and others, 2018; fig. 2).

SPMDs were deployed off either fixed or floating dock structures, or off NPS buoys (table 1). Samplers deployed off the floating dock or buoys remained at the same depth below the water surface throughout deployment as water-levels changed, but elevations of the samples fluctuated; samplers deployed off fixed docks fluctuated in their depth below water surface as water-levels changed, but elevations of the samplers remained the same (fig. 2). Care was taken to deploy the samplers within areas of high boat traffic, away from gasoline pumps, as this study focuses on PAH contamination from boat use. Some of the PAH compounds being sampled for are known to degrade in sunlight (Huckins and others, 2006); therefore, each SPMD was deployed under an attached sun shade to minimize photolysis. Upon collection, all SPMDs were sealed inside of solvent-rinsed, air-tight metal cans, stored below 4 degrees Celsius, and were shipped to arrive at CERC within 7 days of sample collection. 
A.
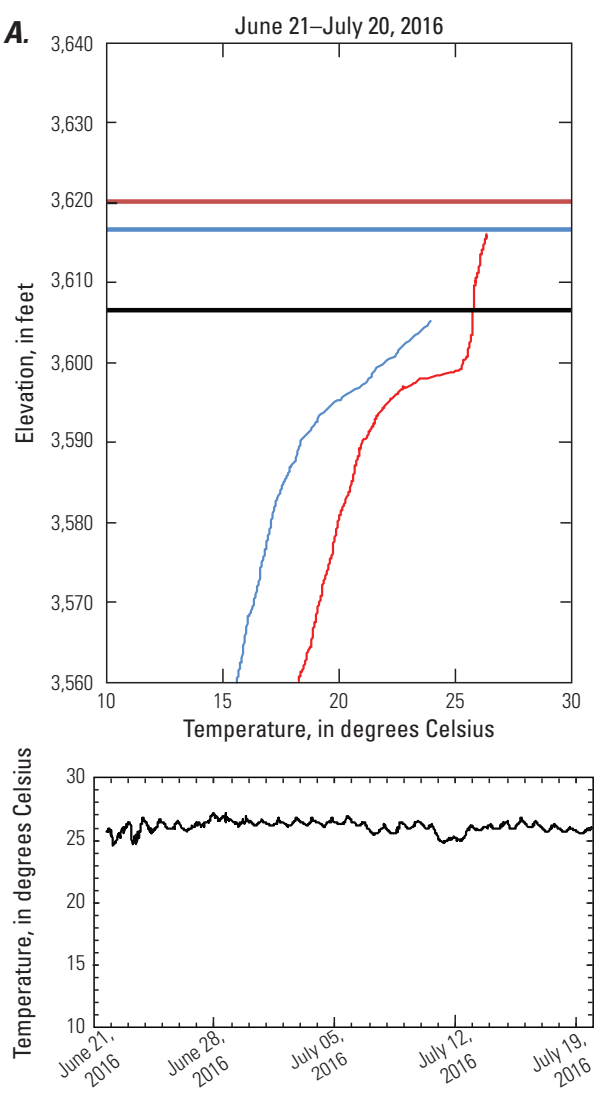

B.
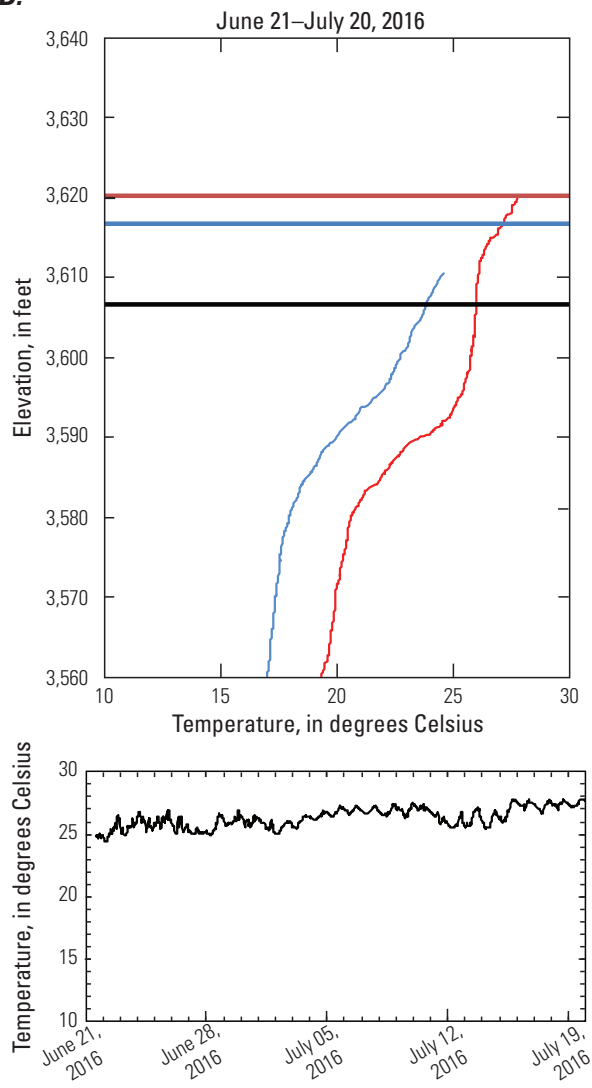
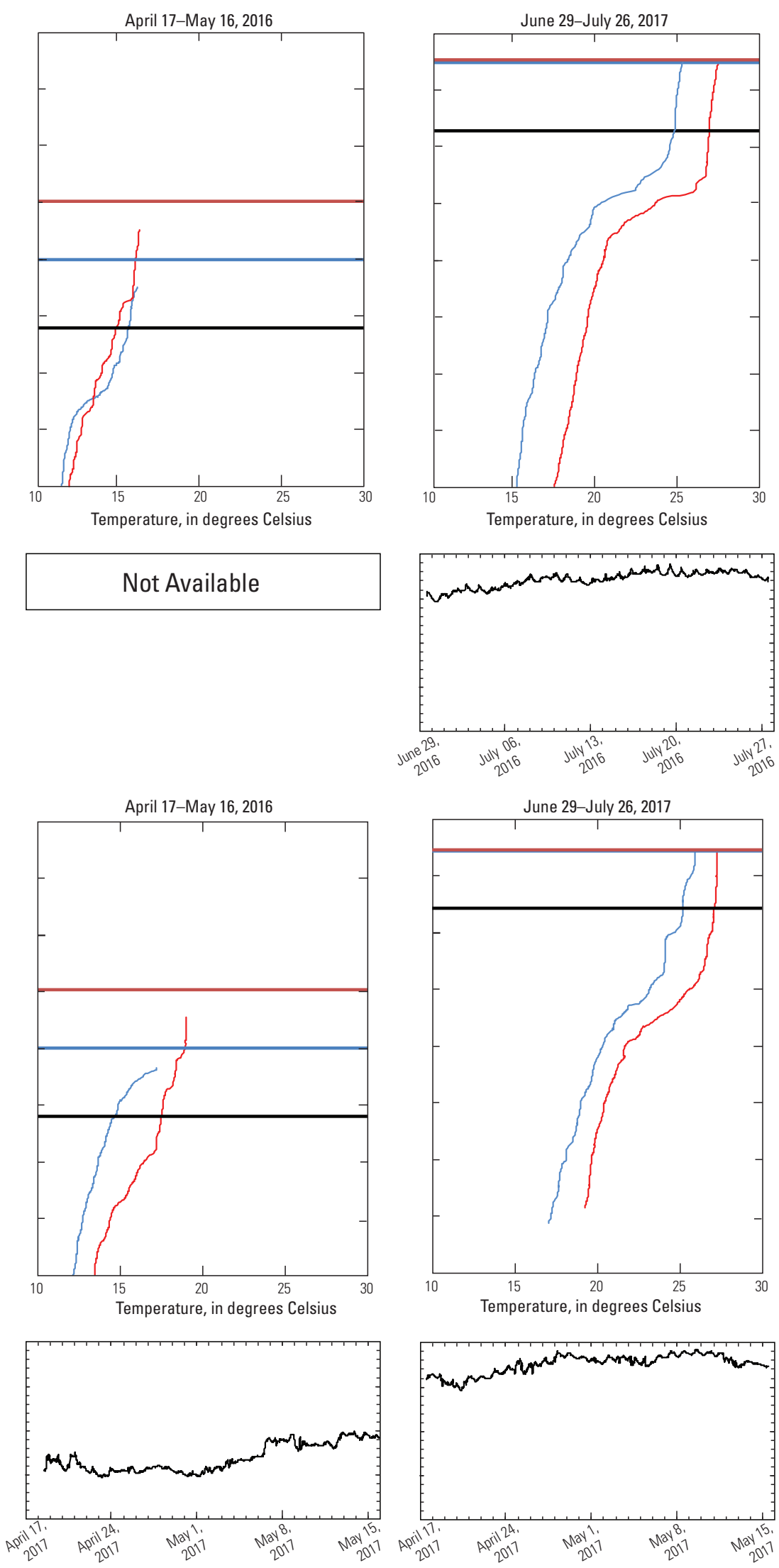

Figure 2. Graphs of the thermocline at semipermeable membrane device (SPMD) deployment and retrieval, and continuous temperature during SPMD deployment period for $(A)$ Antelope Point Marina, $(B)$ Dangling Rope Marina, $(C)$ Lone Rock Beach, $(D)$ Rainbow Bridge National Monument, $(E)$ Stateline Marina, ( $F$ Wahweap Marina, and (G) Warm Creek Bay. [Graphs with no data indicate SPMD was lost and (or) temperature sensor was lost] 

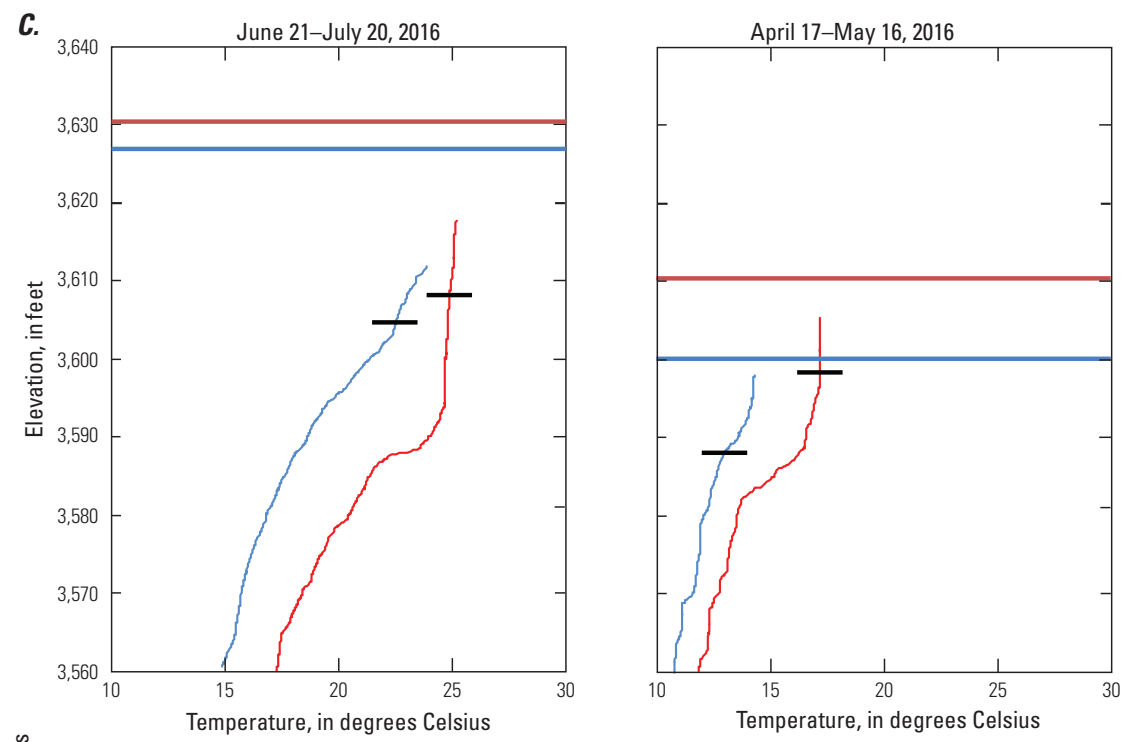

June 29-July 26, 2017

Not Available

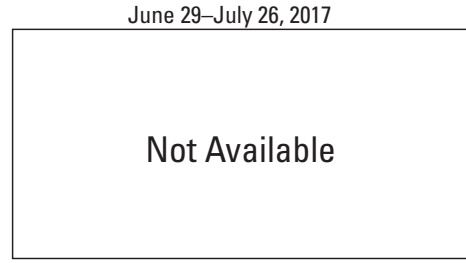

\section{EXPLANATION}

SPMD deployment temperature gradient SPMD retrieval temperature gradient Lake Powell water-surface elevation at deployment

Lake Powell water-surface elevation at retrieval

SPMD elevation
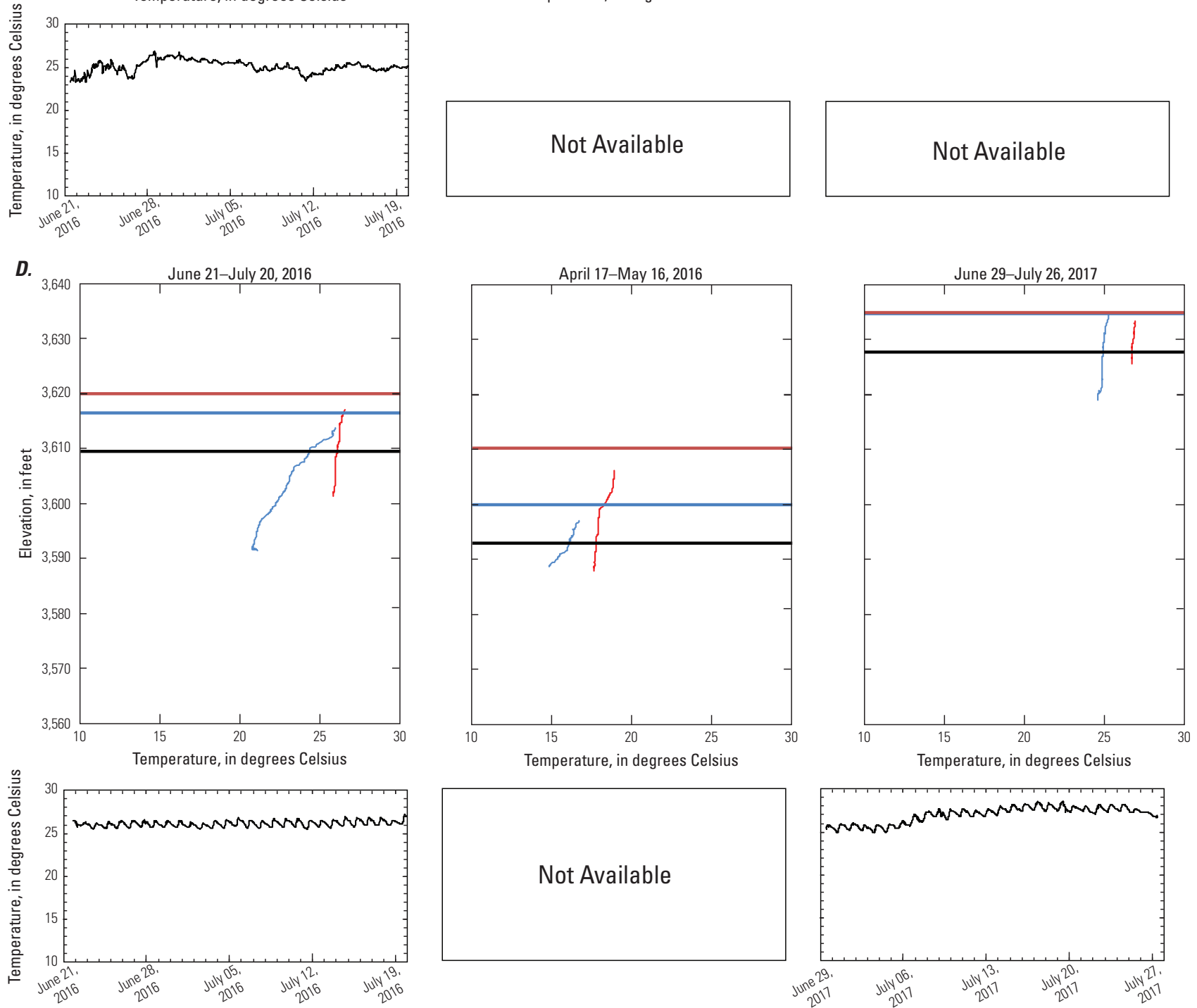

Figure 2. Graphs of the thermocline at semipermeable membrane device (SPMD) deployment and retrieval, and continuous temperature during SPMD deployment period for $(A)$ Antelope Point Marina, $(B)$ Dangling Rope Marina, $(C)$ Lone Rock Beach, (D) Rainbow Bridge National Monument, (E) Stateline Marina, (F) Wahweap Marina, and (G) Warm Creek Bay. [Graphs with no data indicate SPMD was lost and (or) temperature sensor was lost] —Continued. 
E.
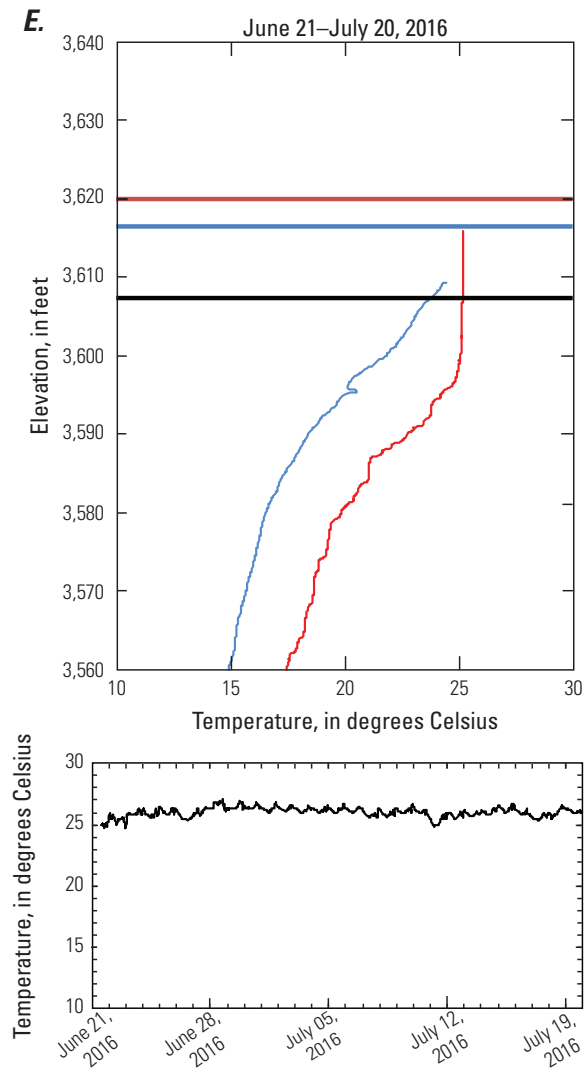

F.
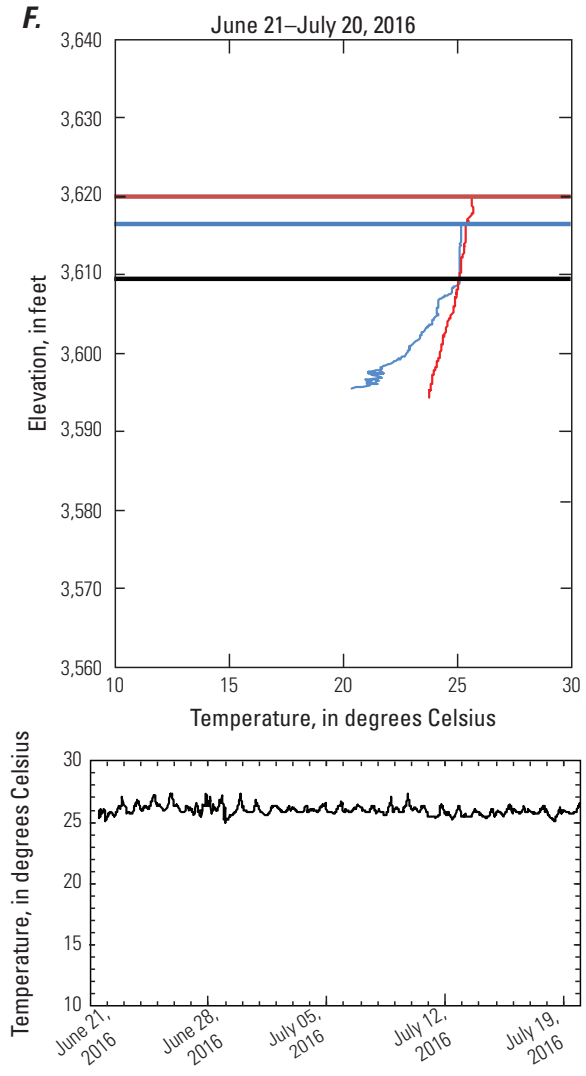
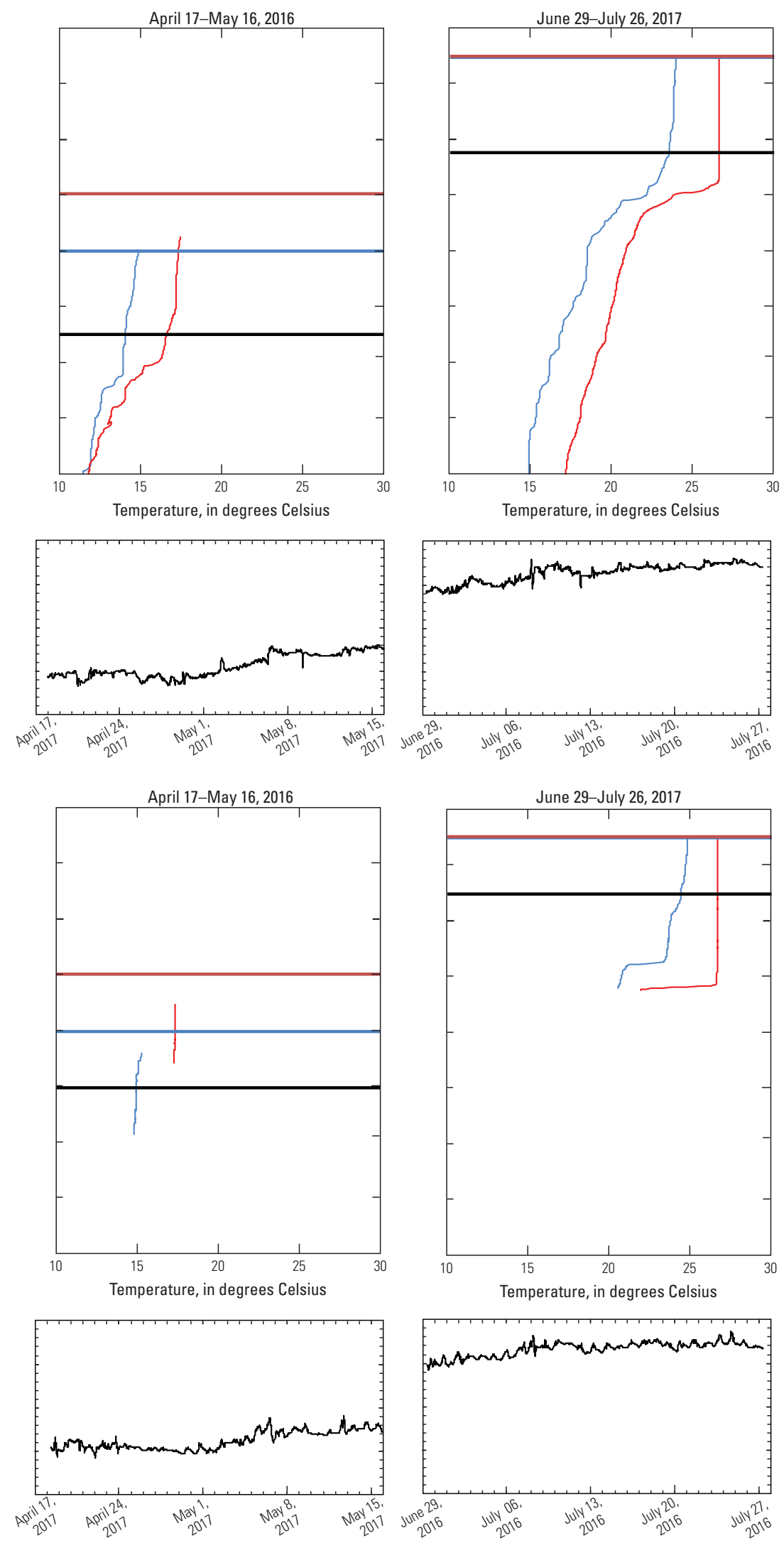

Figure 2. Graphs of the thermocline at semipermeable membrane device (SPMD) deployment and retrieval, and continuous temperature during SPMD deployment period for $(A)$ Antelope Point Marina, $(B)$ Dangling Rope Marina, $(C)$ Lone Rock Beach, $(D)$ Rainbow Bridge National Monument, (E) Stateline Marina, ( $F$ ) Wahweap Marina, and $(G)$ Warm Creek Bay. [Graphs with no data indicate SPMD was lost and (or) temperature sensor was lost]—Continued. 
G.
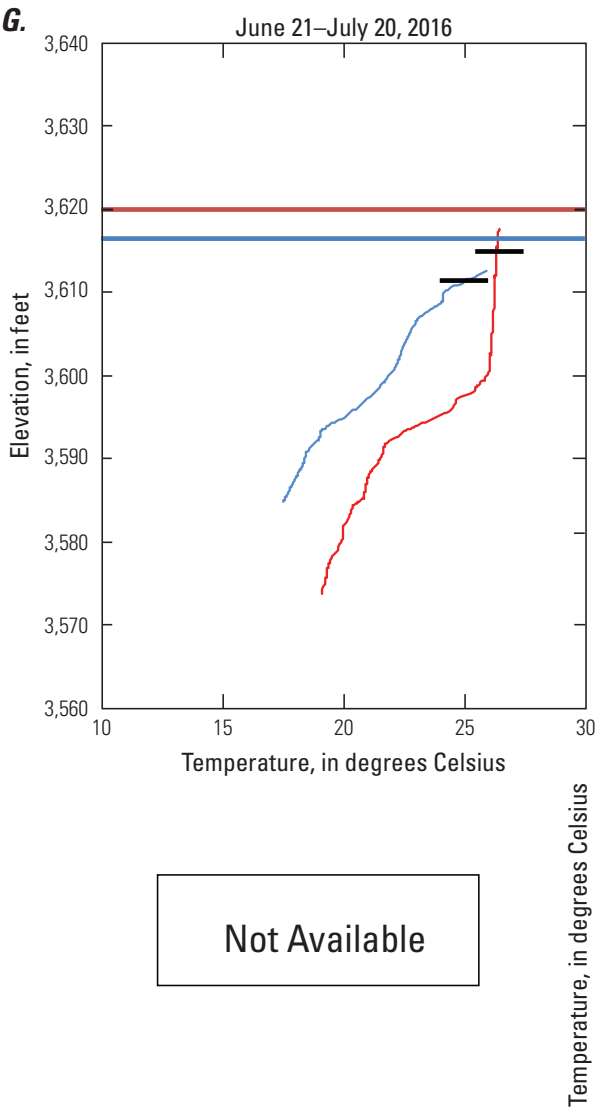
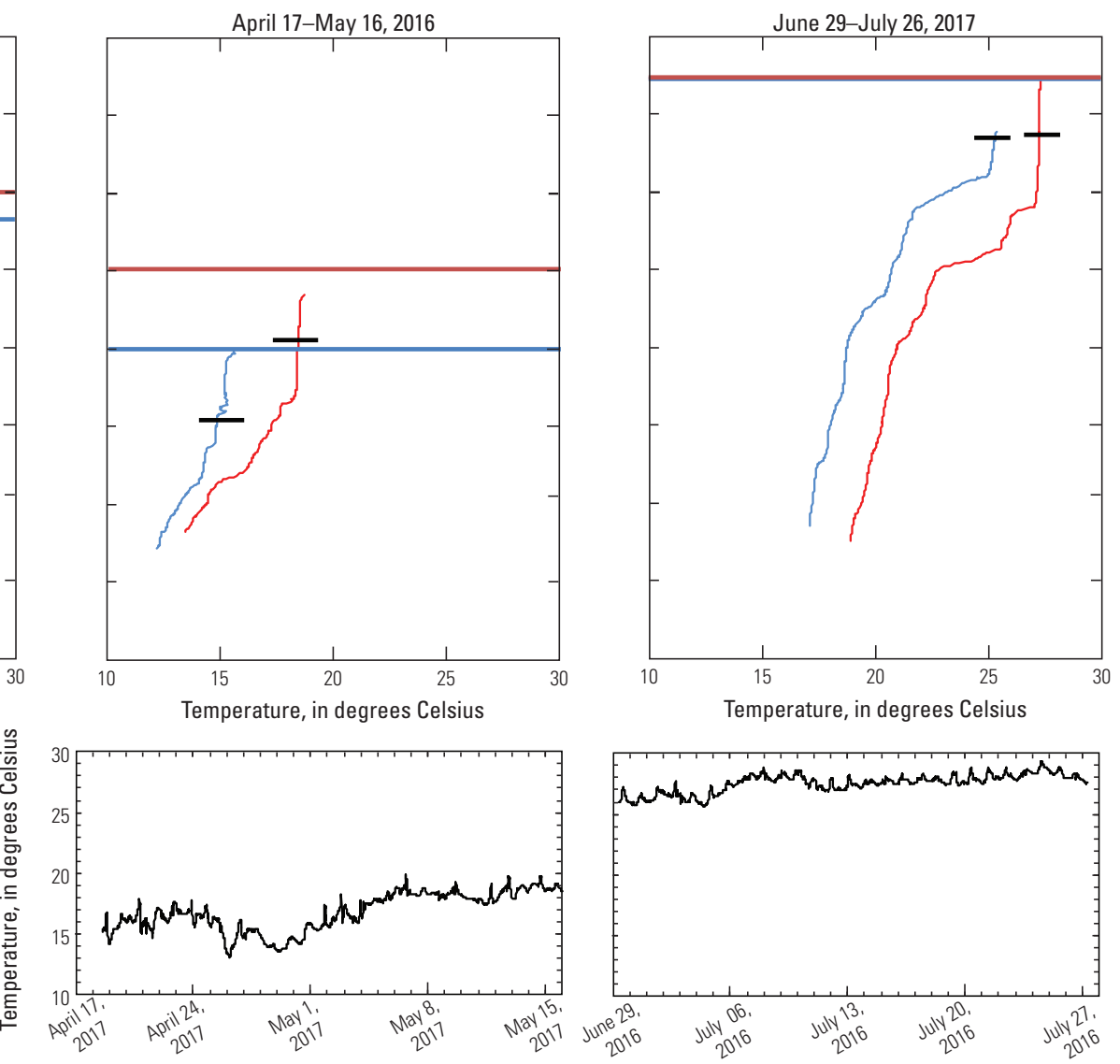

EXPLANATION

SPMD deployment temperature gradient

SPMD retrieval temperature gradient

Lake Powell water-surface elevation at deployment

Lake Powell water-surface elevation at retrieval

SPMD elevation

Figure 2. Graphs of the thermocline at semipermeable membrane device (SPMD) deployment and retrieval, and continuous temperature during SPMD deployment period for $(A)$ Antelope Point Marina, $(B)$ Dangling Rope Marina, $(C)$ Lone Rock Beach, $(D)$ Rainbow Bridge National Monument, (E) Stateline Marina, ( $F$ ) Wahweap Marina, and (G) Warm Creek Bay. [Graphs with no data indicate SPMD was lost and (or) temperature sensor was lost]—Continued. 
Table 1. Description of sampled sites, deployment depths, and quality-control data.

\begin{tabular}{|c|c|c|c|c|c|c|c|c|}
\hline \multirow[t]{2}{*}{ Site name } & \multirow[t]{2}{*}{ Site identifier } & \multirow[t]{2}{*}{$\begin{array}{l}\text { Deployment } \\
\text { location }\end{array}$} & \multicolumn{3}{|c|}{$\begin{array}{c}\text { Deployment depth, feet below water } \\
\text { surface }\end{array}$} & \multicolumn{3}{|c|}{ Field quality control sample } \\
\hline & & & $\begin{array}{c}\text { Summer } \\
2016 \\
\end{array}$ & $\begin{array}{l}\text { Spring } \\
2017\end{array}$ & $\begin{array}{c}\text { Summer } \\
2017\end{array}$ & $\begin{array}{c}\text { Summer } \\
2016 \\
\end{array}$ & $\begin{array}{c}\text { Spring } \\
2017 \\
\end{array}$ & $\begin{array}{c}\text { Summer } \\
2017\end{array}$ \\
\hline $\begin{array}{l}\text { Antelope Point } \\
\text { Marina }\end{array}$ & 365759111254700 & Fixed Dock & 10 & 12 & 12 & Blank & Replicate & None \\
\hline $\begin{array}{l}\text { Dangling Rope } \\
\text { Marina }\end{array}$ & 370708111045100 & Fixed Dock & 10 & 12 & 10 & None & Blank & Replicate \\
\hline Lone Rock Beach & 370107111320500 & Buoy & 12 & 12 & Lost & None & Blank & None \\
\hline Padre Bay & 370321111171700 & Buoy & Lost & Lost & Lost & Blank & None & None \\
\hline $\begin{array}{l}\text { Rainbow Bridge } \\
\text { National } \\
\text { Monument }\end{array}$ & 370506110581600 & Fixed Dock & 7 & 7 & 7 & Blank & None & None \\
\hline Stateline Marina & 370031111300100 & Fixed Dock & 9 & 15 & 17 & Replicate & None & Blank \\
\hline Wahweap Marina & 365933111285200 & Fixed Dock & 7 & 10 & 10 & Blank & None & None \\
\hline Warm Creek Bay & 370333111262700 & Floating Dock & 5 & 9 & 7.5 & Replicate & None & Blank \\
\hline
\end{tabular}

Field QC samples were collected and analyzed according to Alvarez (2010) to assess bias and variability associated with field and laboratory methods. During the three sampling events, eight SPMD field blanks were collected to understand potential high bias caused by introduced contamination associated with all aspects of field and laboratory procedures, and four SPMD field replicates were collected to understand potential variability associated with field conditions and field and laboratory procedures (table 1). Field blanks were collected by exposing a SPMD sampler to the air at the field site during the same length of time that the associated field SPMD was exposed to the air during sampler deployment and retrieval. Field replicates were collected by deploying two SPMDs concurrently at a sampling location so that the samplers were exposed to the same water for the same length of time.

\section{Laboratory Processing and Analysis}

Upon receipt of the SPMD field samples, field blanks, and field replicates at the laboratory, each of the metal cans containing the SPMDs were inspected for damage, logged, and then stored below -20 degrees Celsius. The processing and analysis of the SPMDs for 33 PAHs (table 2) were performed according to methods described in Alvarez and others (2008). In the laboratory, the SPMDs were removed from the deployment canisters and gently cleaned under deionized water to remove any surficial films on the device. The SPMDs were then treated with a two-part dialytic extraction using hexane to recover any sampled PAHs, PRCs, and the photolysis marker. Dialysates were filtered and dried by passing through anhydrous sodium sulfate prior to fractionation using size exclusion chromatography (SEC) to isolate the PAHs from residual lipids, biogenic materials, and sulfur. Following the SEC fractionation, the samples underwent a final cleanup by passing through a gravity-flow chromatography column containing acidic, basic, and neutral silica gel. The samples were then transferred to autosampler vials, spiked with 250 nanograms each of 2-methylnaphthalene- $d_{10}$ and benzo $(e)$ pyrene$d_{12}$ to serve as instrumental internal standards, and the volume adjusted to 1 milliliter of hexane. Analyses were performed using a $6890 \mathrm{~N}$ gas chromatograph coupled with a 5973 mass selective detection (Agilent Technologies, Palo Alto, Calif.). Chromatographic separations were performed using a HP5MS (30 meter, 0.25-millimeter inner diameter, 0.25-micrometer film thickness) column. Details on the chromatographic conditions, mass spectrometer settings, and instrumental calibrations are described in Alvarez and others (2008).

Laboratory QC samples were prepared and analyzed according to Alvarez (2010) to assess bias and variability associated with laboratory methods. Two laboratory blanks, consisting of extract solvent, were manufactured at the same time as extraction of each group of field SPMDs. These blanks were analyzed with field SPMD extracts to understand potential high bias caused by introduced contamination associated with sample processing and analysis. Laboratory matrix spikes were prepared by spiking nondeployed SPMDs in the laboratory with a known quantity of the target PAHs. Two laboratory matrix spikes were analyzed with each group of field-deployed SPMDs to understand potential low or high bias associated with SPMD matrix interference and method performance. The fabrication blanks, previously constructed at the same time as the field SPMDs, were processed and analyzed along with the field SPMDs. These fabrication blanks were analyzed 
Table 2. Method detection and method quantitation limits for each polycyclic aromatic hydrocarbon analyzed as a part of this study.

[Concentrations in picograms per liter; MDL, method detection limit; MQL, method quantitation limit]

\begin{tabular}{|c|c|c|c|c|c|c|}
\hline \multirow[t]{2}{*}{ PAH } & \multicolumn{2}{|c|}{ Summer 2016} & \multicolumn{2}{|c|}{ Spring 2017} & \multicolumn{2}{|c|}{ Summer 2017} \\
\hline & MDL & MQL & MDL & MQL & MDL & MOL \\
\hline Naphthalene & 140 & 680 & $2,2000^{1}$ & $64,000^{1}$ & $27,000^{1}$ & $75,000^{1}$ \\
\hline Acenaphthylene & 28 & 140 & 33 & 170 & 28 & 140 \\
\hline Acenaphthene & 21 & 110 & 27 & 130 & 130 & 380 \\
\hline Fluorene & 16 & 79 & 22 & 110 & 16 & 80 \\
\hline Phenanthrene & 130 & 370 & 99 & 220 & 28 & 70 \\
\hline Anthracene & 12 & 62 & 18 & 91 & 13 & 63 \\
\hline Fluoranthene & 33 & 79 & 180 & 490 & 14 & 36 \\
\hline Pyrene & 15 & 33 & 170 & 470 & 15 & 38 \\
\hline Benz $[a]$ anthracene & 15 & 45 & 35 & 100 & 6.7 & 34 \\
\hline Chrysene & 29 & 88 & 56 & 160 & 6.6 & 33 \\
\hline Benzo $[b]$ fluoranthene & 32 & 95 & 95 & 290 & 6.6 & 33 \\
\hline Benzo $[k]$ fluoranthene & 31 & 94 & 49 & 140 & 7.3 & 36 \\
\hline Benzo $[a]$ pyrene & 21 & 63 & 40 & 120 & 7.7 & 39 \\
\hline Indeno $[1,2,3-c, d]$ pyrene & 31 & 94 & 160 & 440 & 9.4 & 47 \\
\hline Dibenz $[a, h]$ anthracene & 26 & 79 & 67 & 170 & 8.3 & 41 \\
\hline Benzo $[g, h, i]$ perylene & 38 & 120 & 210 & 580 & 10 & 51 \\
\hline Benzo $[b]$ thiophene & 530 & 2,600 & 530 & 2,600 & 530 & 2,600 \\
\hline 2-methylnaphthalene & 150 & 440 & 100 & 250 & 110 & 280 \\
\hline 1-methylnaphthalene & 84 & 260 & 56 & 250 & 59 & 230 \\
\hline Biphenyl & 83 & 250 & 140 & 280 & 43 & 210 \\
\hline 1-ethylnaphthalene & 16 & 78 & 21 & 110 & 16 & 79 \\
\hline 1,2-dimethylnaphthalene & 20 & 98 & 25 & 130 & 20 & 99 \\
\hline 4-methylbiphenyl & 370 & 700 & 1,100 & 2,200 & 590 & 1,100 \\
\hline 2,3,5-trimethylnaphthalene & 8.3 & 72 & 14 & 70 & 8.5 & 43 \\
\hline 1-methylfluorene & 7.9 & 39 & 14 & 68 & 8.1 & 40 \\
\hline Dibenzothiophene & 16 & 79 & 22 & 110 & 16 & 80 \\
\hline 2-methylphenanthrene & 12 & 42 & 21 & 71 & 8.6 & 43 \\
\hline 9-methylanthracene & 7.4 & 37 & 13 & 66 & 7.6 & 38 \\
\hline 3,6-dimethylphenanthrene & 6.4 & 32 & 12 & 62 & 6.7 & 33 \\
\hline 2-methylfluoranthene & 6.4 & 32 & 12 & 62 & 6.7 & 33 \\
\hline Benzo $[b]$ naphtho[2,1- $d]$ thiophene & 16 & 49 & 12 & 62 & 6.8 & 34 \\
\hline Benzo $[e]$ pyrene & 49 & 140 & 150 & 420 & 7.9 & 39 \\
\hline Perylene & 15 & 47 & 14 & 70 & 7.1 & 35 \\
\hline
\end{tabular}

${ }^{1}$ Naphthalene MDLs and MQLs are relatively high because of elevated concentrations in the laboratory blanks, resulting in high means and standard deviations for these sets of blanks. 
to understand potential high bias caused by contamination associated with SPMD fabrication and storage, and sample processing and analysis.

Method detection limits (MDLs) and method quantitation limits (MQLs) were calculated for each field sampling period. The MDLs and MQLs were estimated from the mean and standard deviation of PAH residues measured in the SPMD fabrication, laboratory, and field blanks as previously described (Alvarez, 2010; Keith, 1991). The MDL was calculated as the mean plus three times the standard deviation of a PAH's concentration in the blanks. The MQL was calculated as the mean plus ten times the standard deviation of a PAH's concentration in the blanks. In cases where a PAH was not measured in any of the blanks, the MQL was set to the concentration of the lowest calibration standard used during the analysis and the MDL was set to 20 percent of the MQL.

Conversion of concentration in units of mass per SPMD to mass per volume water for each PAH was conducted using uptake models described in Huckins and others (2006). All PAH data in units of nanogram per SPMD are archived in the USGS National Water Information System database (U.S. Geological Survey, 2018) and by Mayo and others (2018). All PAH data in units of picogram per liter are archived by Mayo and others (2018).

\section{Data Analysis}

PAH concentrations and detections were statistically compared between sampling sites, summer and spring deployment periods, and historical and present conditions. Censored statistical methods were used to quantify and represent PAH concentrations that were below the MDLs. Censored box-plot analyses using the "cenboxplot" function and robust regression on order statistics (ROS) using the "cenros" function from the NADA package in R (Lee, 2015) was used to calculate the median, mean, and standard deviation for comparison using the "cendiff" function from the NADA package in R (Lee, 2015). The "cendiff" function uses the Peto-Prentice test (Helsel and Lee, 2006) to determine whether there were significant differences between the groups for elements with censored data. ROS is a robust estimator and the least biased estimator, except for when censoring level is above 50 percent. When estimating the mean, the ROS is also generally a better estimator and has lower biases for the mean (Annan and others, 2009). If concentrations for a PAH were not censored, then traditional nonparametric approaches were used to compute general statistics and pairwise testing was completed with a Wilcoxon Rank Sum Test.

A nonmetric multidimensional scaling (NMDS) multivariate analysis procedure was used to compare samples with different MDLs from different locations (Clarke and Gorley, 2006). The NMDS analysis was performed on a Bray-Curtis similarity matrix and plotted in two-dimensional space to aid in interpretation of multivariate patterns. A Bray-Curtis similarity matrix is well suited for PAH data because of the flexibility to include one or more censored data pairs into the matrix calculation.
A measure of stress is provided from the NMDS analysis as a diagnostic to determine how well the data are fitting the NMDS ordination. Lower stress values are desired, and stress values below 0.20 generally indicate that the NMDS plot is providing an accurate representation of the data in multivariate space.

A multivariate analysis of similarities (ANOSIM) was used in group comparisons. ANOSIM is a distribution-free method to compare the variation in analytes and concentration among sampling units in terms of some grouping factor or experimental treatment levels. ANOSIM was used to test the group factors of locations and sampling period. Linkage trees (LINKTREE) were used in conjunction with the similarity profile routine (SIMPROFF) to generate information about samples that plotted close together in the NMDS (Clarke and others, 2008). LINKTREE is a nonparametric version of multivariate regression trees or classification and regression trees. It optimizes successive binary divisions of sample patterns using threshold values of PAH variables and provides information about groupings in terms of single PAH variables. SIMPROF was used to objectively identify clusters or groups of samples. The routine was run at the same time as the LINKTREE in order to strengthen grouping patterns identified in the NMDS. Significant groupings were identified, and PAHs used in the binary divisions were identified. Redundant PAHs leading to the same division were all listed for each group.

\section{Sampling Conditions}

Lake Powell is stratified and considered to be a meromictic reservoir where layers of water do not intermix (Hart and Sherman, 1996). This is particularly true in the deepest part of the reservoir, the forebay of Glen Canyon Dam, where the lake is over 500 feet deep. Water levels in Lake Powell tend to increase from May through July with spring runoff and decrease through the rest of the year as water is released from Glen Canyon Dam for users downstream (Bureau of Reclamation, 2018; fig. 3). The water-surface elevation of Lake Powell during the summer sampling events were 7 to 36 feet higher than during the spring sampling event. Elevations ranged from 3,617 to 3,621 feet during the summer 2016 sampling event, and from 3,635 to 3,636 feet during the summer 2017 sampling event, whereas elevations ranged from 3,600 to 3,610 feet during the spring 2017 sampling event. The water-surface elevation of Lake Powell during 2016-17 sampling was relatively low compared to long-term (38 year) water-surface elevations, but similar to elevations in the last 10-15 years (fig. 3b).

Water-surface elevations during the summer 2016 and summer 2017 sampling events were 21 to 44 feet lower than during the summer 2010 sampling event.

Water temperatures at the SPMD deployment depths remained fairly constant during the deployment periods, and all SPMDs remained in the epilimnion during deployment (Mayo and others 2018; fig. 2). With one exception, temperatures slightly increased at all sites during SPMD deployment, 


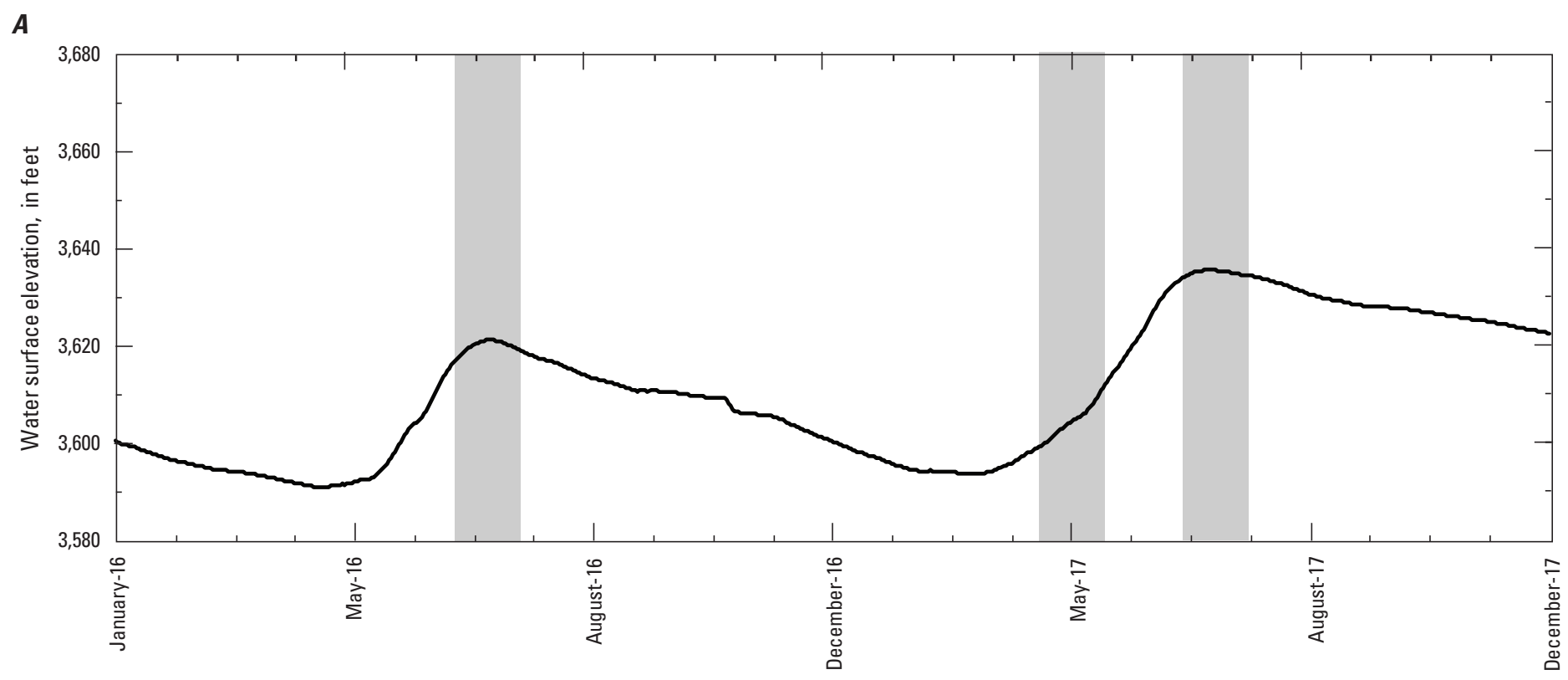

$\boldsymbol{B}$

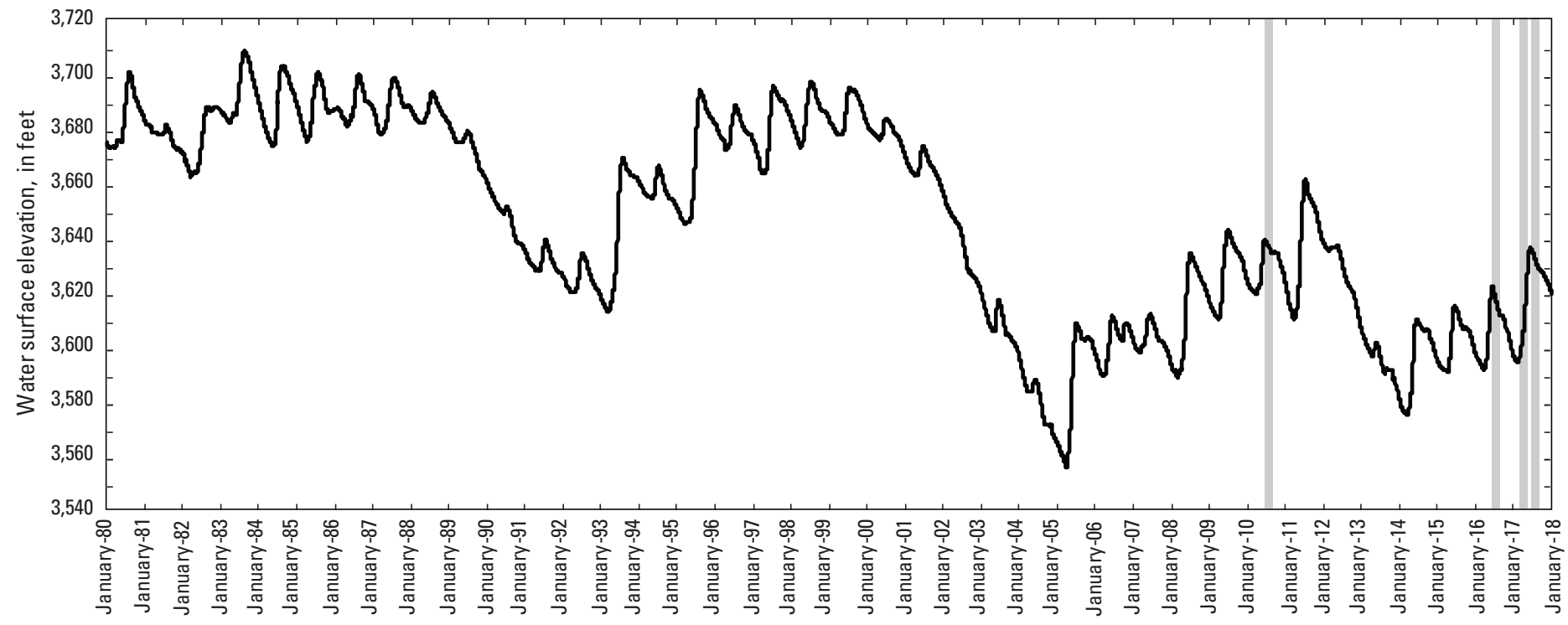

Figure 3. Water surface elevation graphs of Lake Powell from $(A)$ 2016-17, and $(B)$ 1980-2017 (Bureau of Reclamation, 2018). [Shaded areas represent time periods when semipermeable membrane devices were deployed]

with a largest temperature increase of 6.8 degrees Celsius at the Warm Creek Bay site, during the spring 2017 deployment. Water temperatures slightly decreased at the Antelope Point Marina site during the spring 2017 deployment. Unfortunately, the TidbiT water temperature data logger failed at this site during this deployment, but the Sea-Bird temperature and depth profiler data indicated a temperature decrease of about 0.5 degrees Celsius.

Monthly boat rental and boat mooring information for Wahweap Marina, available from the NPS, was used in this report as an indicator of watercraft use on the southern end of Lake Powell. The summer 2016 and summer 2017 SPMD deployments were during the periods of typically high boat use, and the spring 2017 deployment was during a period of typically low boat use (fig. 4). The average of monthly boat rentals (total of houseboat and powerboat rentals at Wahweap Marina) was 3,592 boats in June-July 2016 and 3,681 boats in JuneJuly 2017, wheras the average of monthly rentals was 798 boats in April-May 2017. During the July-August 2010 sampling, the average of monthly rentals was 3,695 boats. Average monthly boat mooring occupancy (total occupied slips and buoys at Wahweap Marina) was generally consistent during the 2016-17 study, with 685 occupied in June-July 2016, 620 occupied in April-May 2017, and 659 occupied in June-July 2017. During the July-August 2010 sampling, average monthly mooring occupancy was slightly higher at 789 occupied. 
$\boldsymbol{A}$

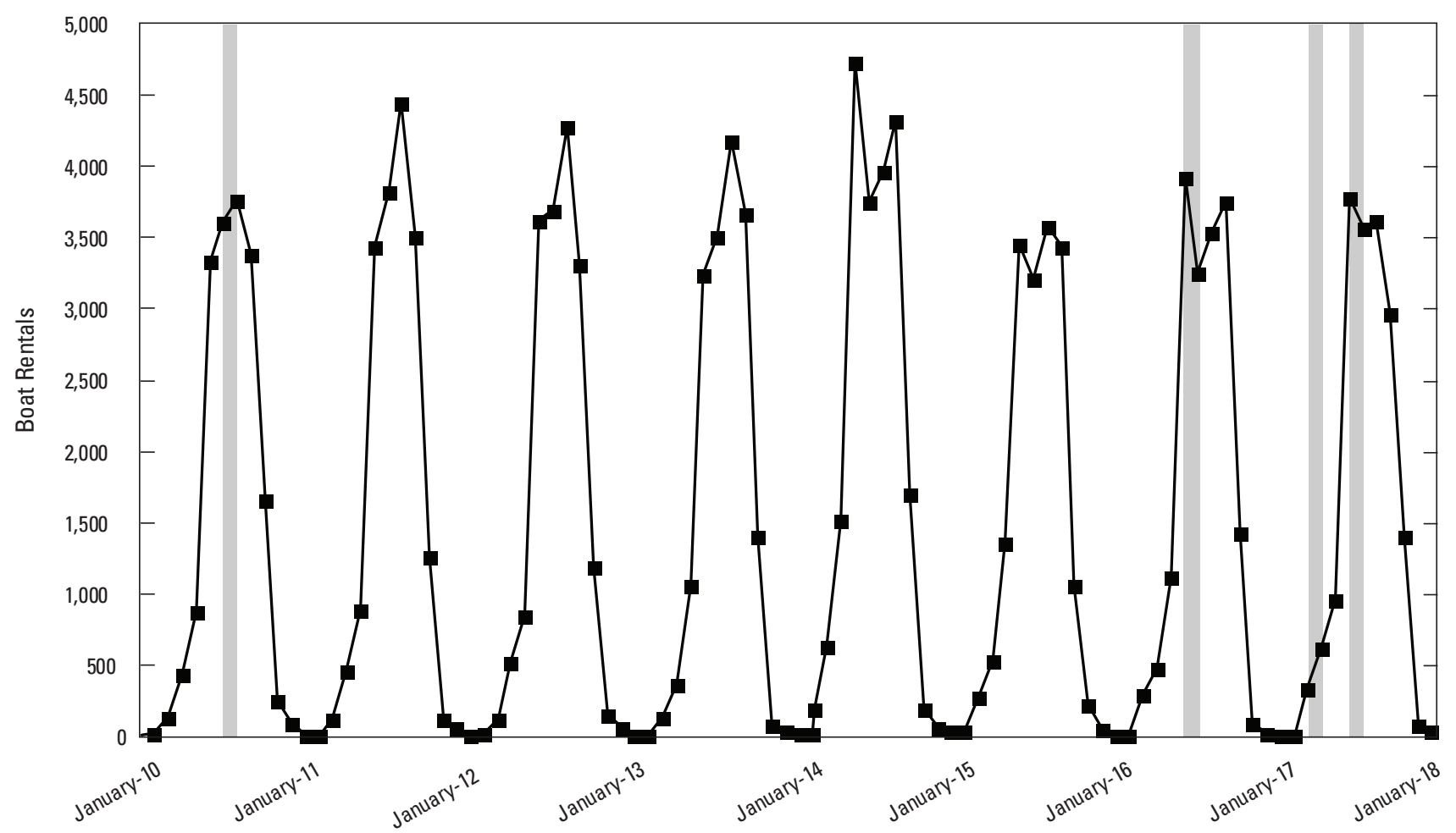

B

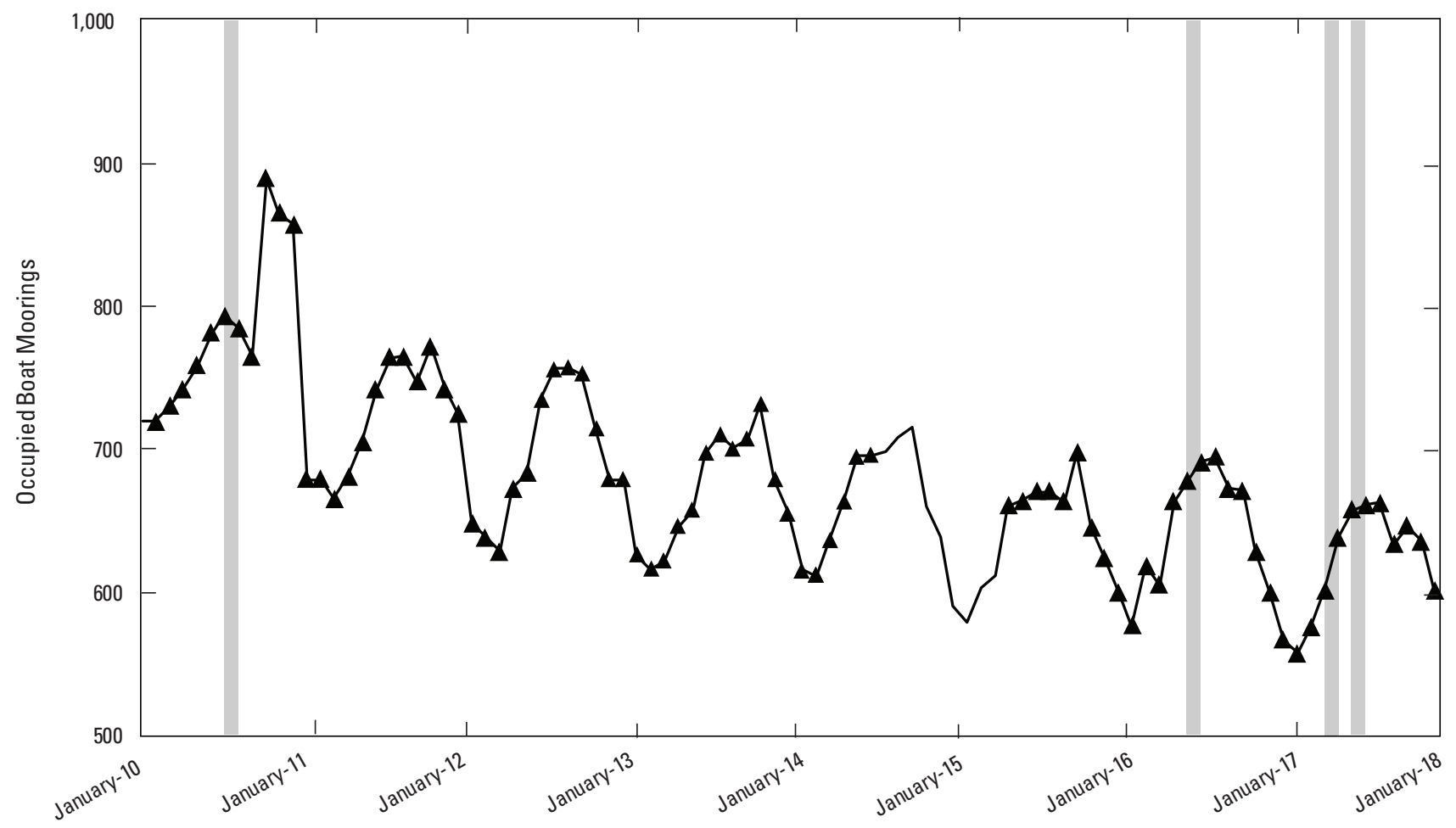

Figure 4. Graphs of monthly boat use in Lake Powell in terms of: $(A)$ boat rentals at Wahweap Marina, and $(B)$ occupied boat moorings Weheap Marina, 2010-17 (data available from National Park Service). [Shaded areas represent time periods when semipermeable membrane devices were deployed; boat rentals are the total monthly powerboat and houseboat rentals at Wahweap Marina; boat moorings are the total monthly occupied slips and buoys at Wahweap Marina] 


\section{Data Quality Assessment}

All PAH QC data are archived in Mayo and others (2018). The field and laboratory PAH QC data indicate that there are acceptably low levels of bias and variability affecting the environmental PAH data. Combining the 6 fabrication, 6 laboratory, and 8 field blank samples, the upper confidence limit is 96 percent that potential contamination is no greater than the MDL of any given PAH in at least 85 percent of the samples. Average relative percent differences (RPDs) in the 4 field replicate samples ranged from 0 to 22 percent for the 24 PAH compounds with detections in the replicate pairs; only four PAHs had average RPDs greater than 15 percent (pyrene, benzo $[k]$ fluoranthene, 3,6-dimethylphenanthrene, and 2-methylfluoranthene). Average recoveries in the 6 laboratory matrix spike samples ranged from 42 to 89 percent. One PAH had an average recovery below 50 percent, and 14 PAHs had average recoveries between 50 and 75 percent (table 3). Twelve of these PAHs were detected in Lake Powell during this study, but reported concentrations may be biased low. Recoveries of the photolysis marker dibenz $[a, h]$ anthracene- $d_{14}$ ranged from 80 to 109 percent, indicating that there is likely very little potential low bias in the PAH concentrations because of degradation upon exposure to sunlight.

Table 3. Polycyclic aromatic hydrocarbons with average recoveries less than 75 percent.

[Average of 6 laboratory matrix spike samples; PAHs in bold font were detected during the 2016-17 sampling]

\begin{tabular}{lc}
\hline Polycyclic aromatic hydrocarbons & $\begin{array}{c}\text { Average recovery, in } \\
\text { percent }\end{array}$ \\
\hline Naphthalene & 61 \\
Acenaphthylene & 60 \\
Acenaphthene & 62 \\
Fluorene & 67 \\
Benzo[b]thiophene & 42 \\
2-methylnaphthalene & 50 \\
1-methylnaphthalene & 50 \\
Biphenyl & 55 \\
1-ethylnaphthalene & 58 \\
1,2-dimethylnaphthalene & 61 \\
4-methylbiphenyl & 71 \\
2,3,5-trimethylnaphthalene & 69 \\
1-methylfluorene & 74 \\
Dibenzothiophene & 72 \\
Perylene & 67 \\
\hline
\end{tabular}

\section{Polycyclic Aromatic Hydrocarbon Concentrations}

Twenty-eight out of the 33 PAHs analyzed were detected in Lake Powell during 2016-17 in at least 1 of the 3 sampling events (fig. 5). The only PAHs not detected were acenaphthene, benzo[ $a]$ pyrene, dibenzothiophene, 9-methylanthracene, and perylene. PAHs were detected at all seven of the sites where samples were successfully collected (fig. 6). To understand differences between the sampled sites in terms of PAH detections and concentrations, the total number of PAHs detected at each site over the three sampling events was compared to the following: 1) the sum of all of the PAH concentrations at each site over the three sampling events at each site, and 2) the median rank of all of the ranked PAH concentrations at each site over the three sampling events (fig. 7). Antelope Point Marina and Wahweap Marina had the highest total number of detections at the highest concentrations, followed by Stateline Marina. Dangling Rope Marina had the lowest number of detections at the lowest concentrations. Lone Rock Beach is not included in this analysis because the summer 2017 sample was lost and the number of detections is therefore not comparable to the other sites.

Of the 28 PAHs detected, 16 were detected from all 3 sampling events. Twelve PAHs were detected from one or both of the summer sampling events but were not detected during the spring sampling event (fig. 5). To understand differences between the spring and summer samples in terms of PAH detections and concentrations, the total number of PAHs detected at each site during each sampling event was compared to the following: 1) the sum of all of the PAH at each site during each sampling event, and 2) the median rank of all of the ranked PAH concentrations at each site during each sampling event (fig. 8). The summer 2016 and summer 2017 samples generally have higher numbers of detections at the highest concentrations than spring 2017 samples. For each sampling event, the samples at Antelope Point Marina and Wahweap Marina have the highest number of detections at the highest concentrations, and Dangling Rope Marina has the lowest number of detections at the lowest concentrations (fig. 8). This low to high gradient of detections and concentrations was corroborated by a NMDS multivariate analysis, which was used to analyze patterns between locations both spatially and temporally (fig. 9). In the NMDS, samples are represented as a single data point, but incorporate all $\mathrm{PAH}$ concentrations quantified for that sample (that is, via the similarity matrix). The 2016 and 2017 samples show a general clustering of spring samples separate from summer samples. A pair-wise test (differences between similarity matrices) indicates that the spring sample is significantly different than the summer samples (ANOSIM test, summer 2016 to spring 2017 and summer 2017 to spring 2017, p = 0.002 and 0.001, respectively). Spring and summer samples from Antelope Point Marina and Wahweap Marina are on the high end of the 


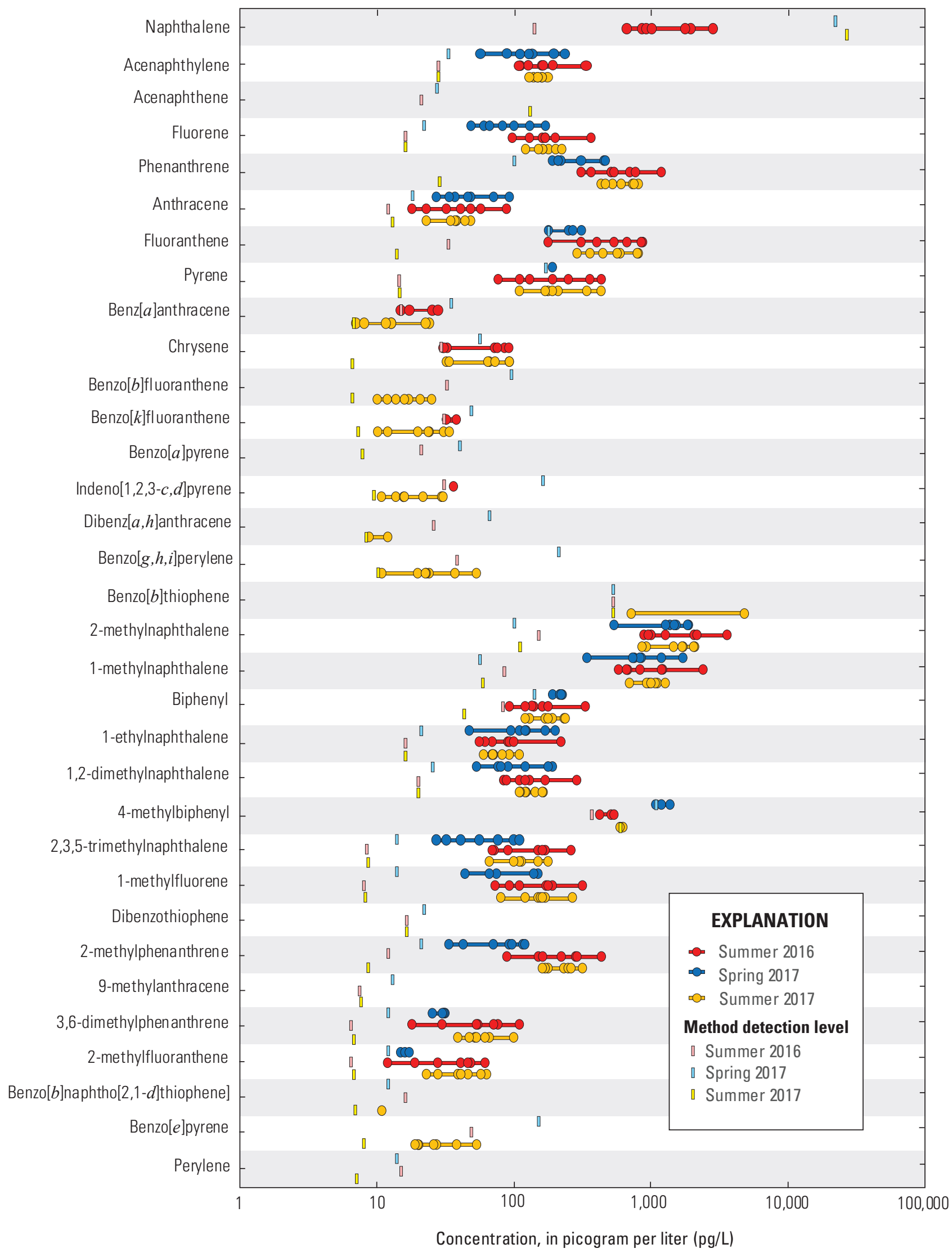

Figure 5. Diagram of polycyclic aromatic hydrocarbon concentrations at Lake Powell monitoring sites, 2016-17. 


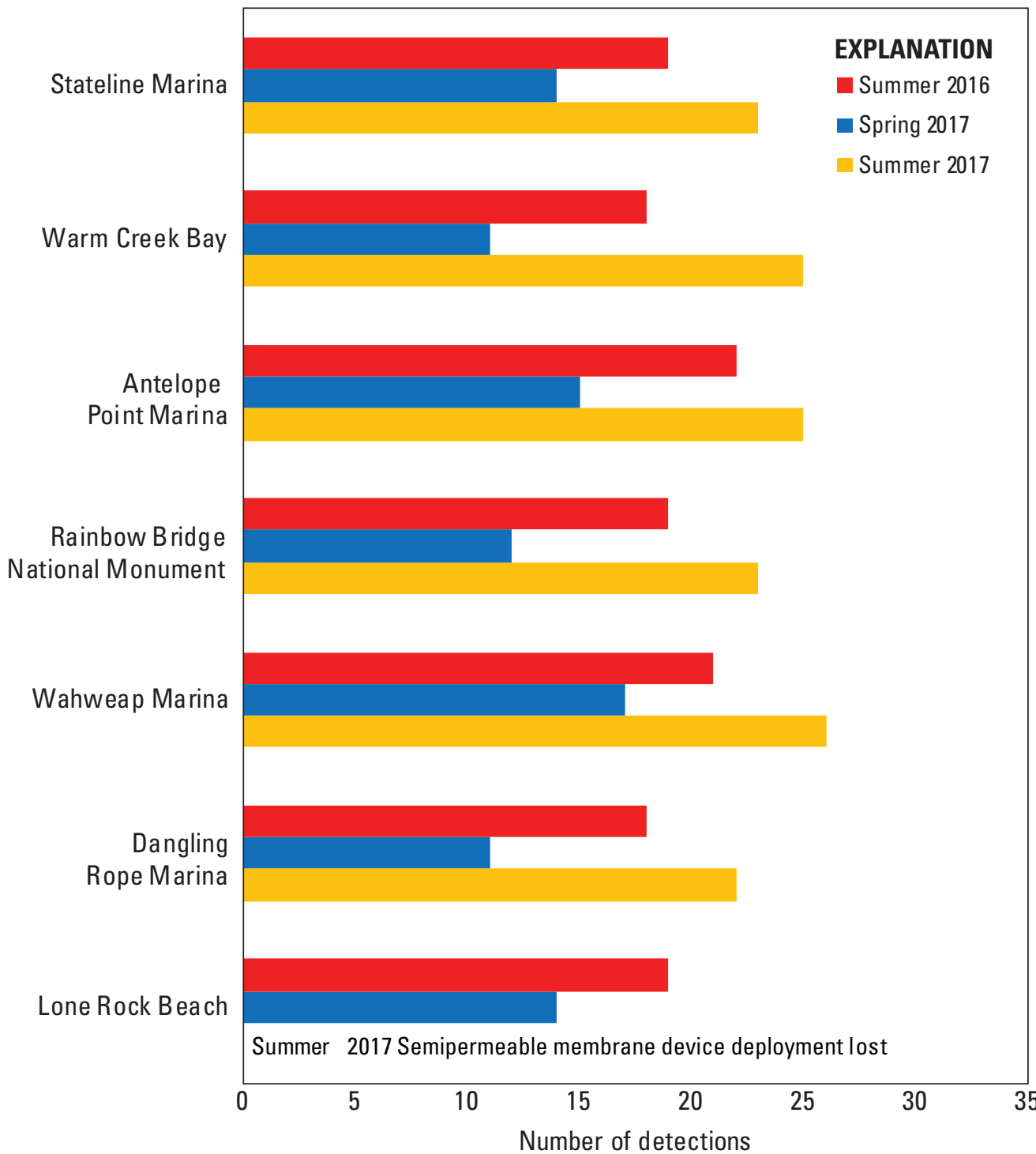

Figure 6. Graph showing number of polycyclic aromatic hydrocarbon detections at Lake Powell monitoring sites, 2016-17.

A

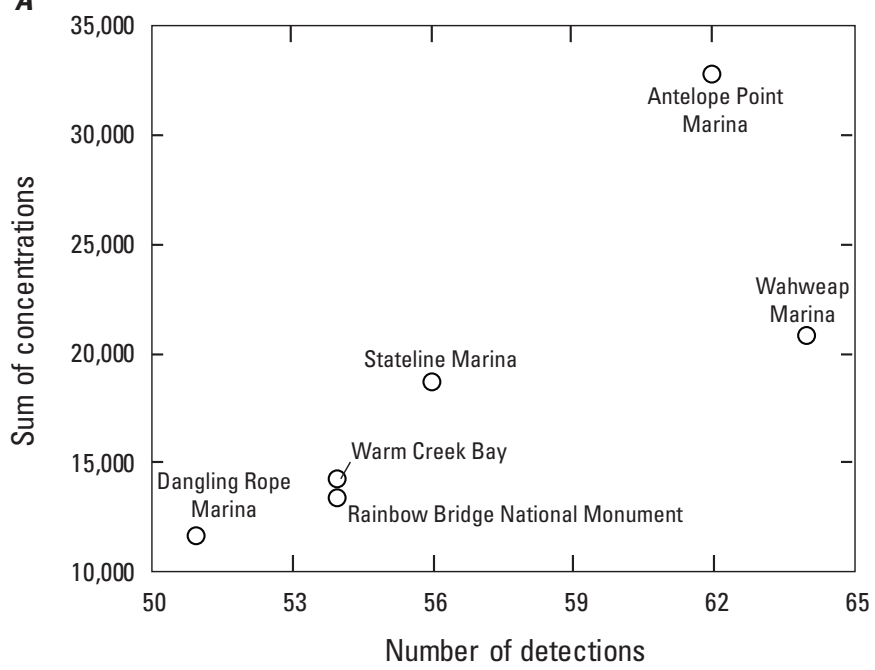

B

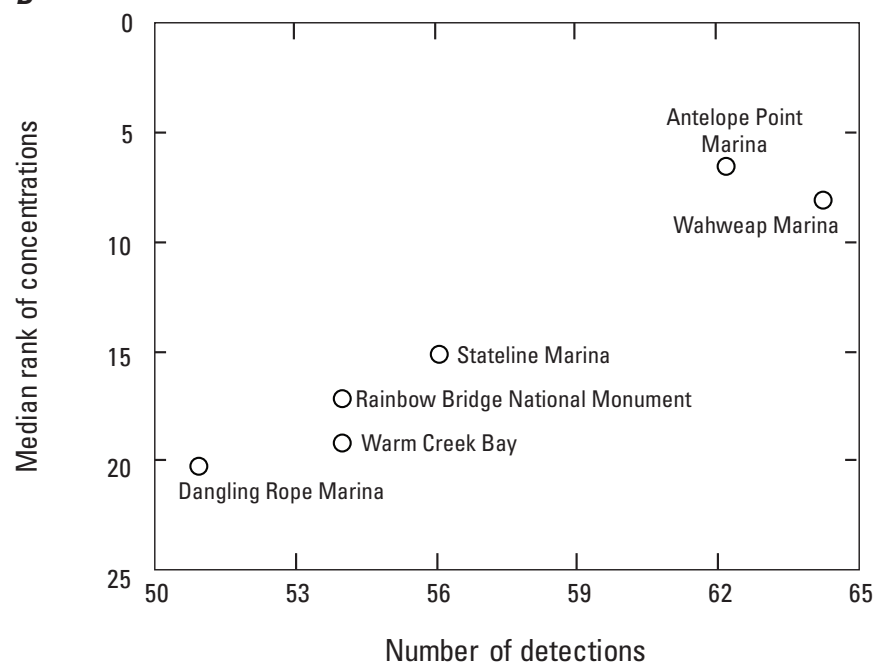

Figure 7. Graph showing total number of polycyclic aromatic hydrocarbons detected at Lake Powell monitoring sites over the three sampling events, 2016-17, compared to: (a) the sum of all of the polycyclic aromatic hydrocarbon concentrations at each site over the three sampling events, and (b) the median rank of all of the ranked polycyclic aromatic hydrocarbon concentrations at each site over the three sampling events. 

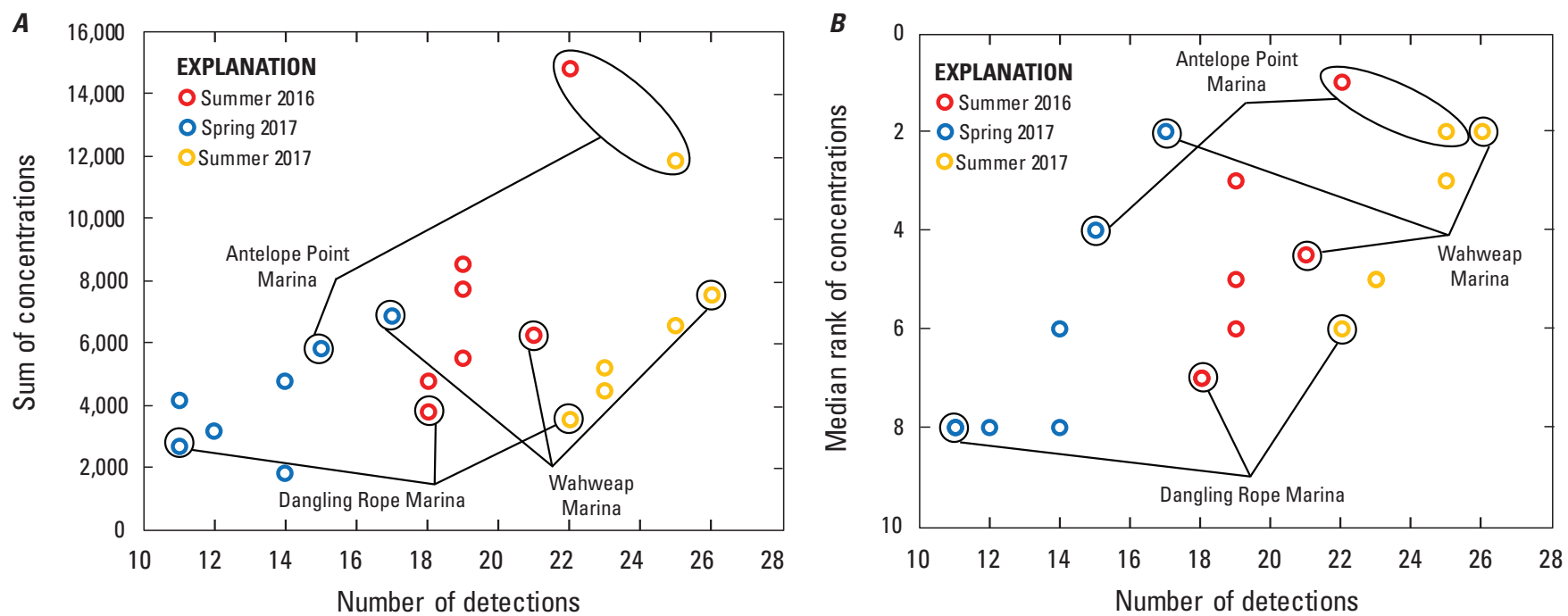

Figure 8. Graphs illustrating the total number of polycyclic aromatic hydrocarbons detected at Lake Powell monitoring sites during each sampling event, 2016-17, compared to: 1) the sum of all of the polycyclic aromatic hydrocarbon concentrations at each site during each sampling event, and 2) the median rank of all of the ranked polycyclic aromatic hydrocarbon concentrations at each site during each sampling event.

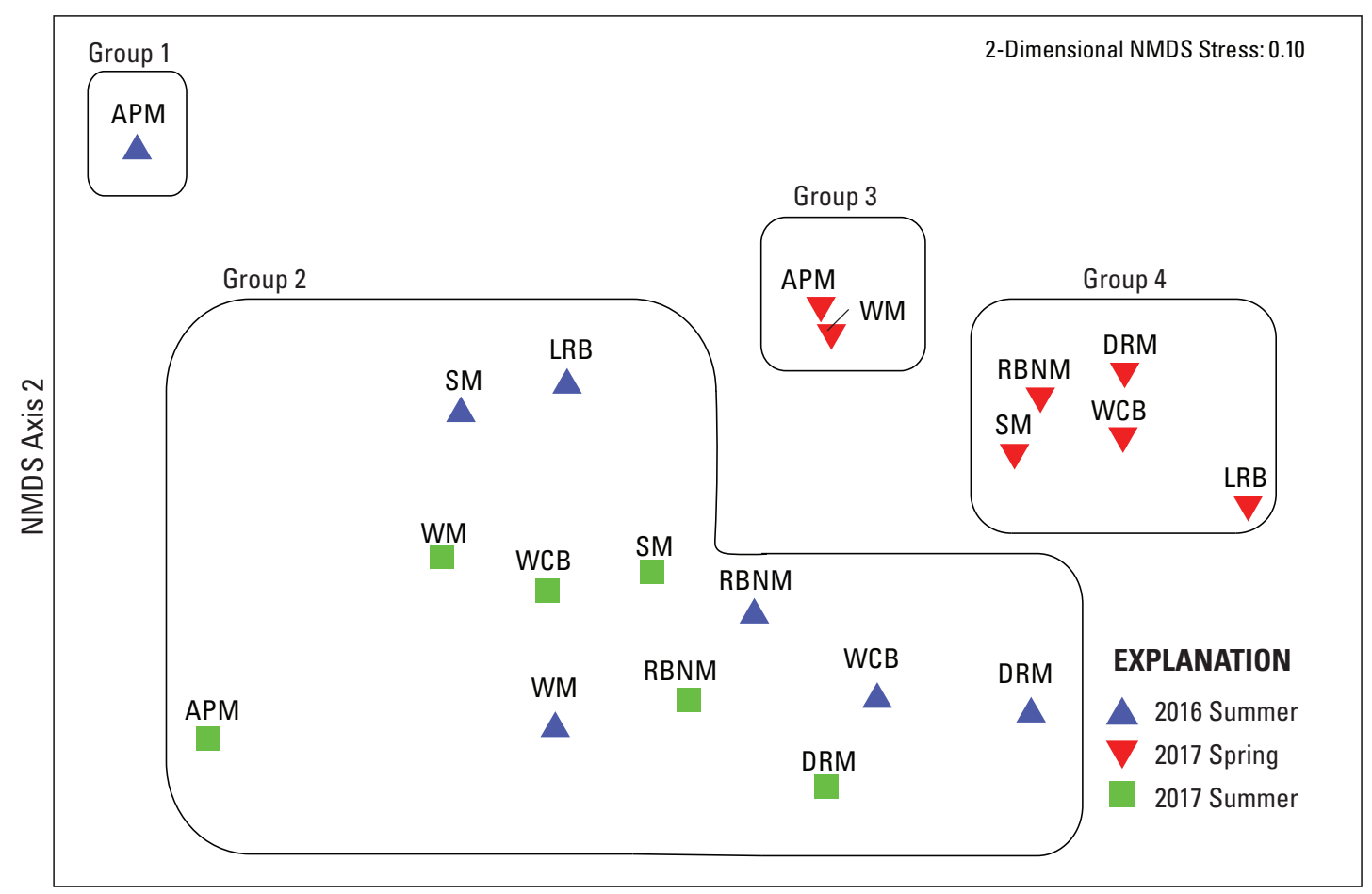

NMDS Axis 1
Figure 9. Diagram showing nonmetric multidimensional scaling (NMDS) ordination plot of polycyclic aromatic hydrocarbon concentrations at Antelope Point Marina (APM), Dangling Rope Marina (DRM), Lone Rock Beach (LRB), Rainbow Bridge National Monument (RBNM), Stateline Marina(SM), Wahweap Marina (WM), and Warm Creek Bay (WCB) during each sampling event, 2016-17. Compounds and concentrations used in the group designations are listed in table 4. detection-concentration gradients (left side), summer samples from Dangling Rope Marina are on the low end of the detection-concentration gradient (right side), and the spring sample from Lone Rock Beach is on the low end of the detectionconcentration gradient (right side). There was not a significant difference between 2016 and 2017 summer samples.

Concentrations of 10 PAHs (fluorene, phenanthrene, fluoranthene, pyrene, chrysene, 2,3,5-trimethylnaph thalene, 1-methylfluorene, 2-methylphenanthrene, 3,6-dimethylphenanthrene, and 2-methylfluoranthene) were significantly higher in the summer samples than in the spring samples (fig. 10). Concentrations of one PAH (4-methylbiphenyl) was significantly higher in the spring sample than in the summer samples (fig. 10). A classification routine (LINKTREE) 

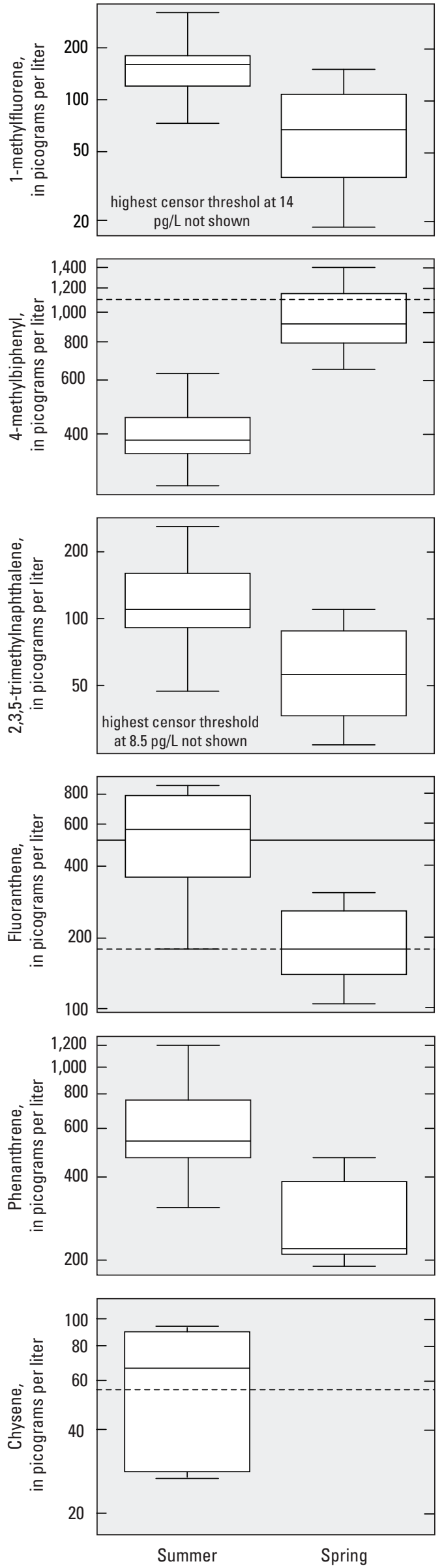
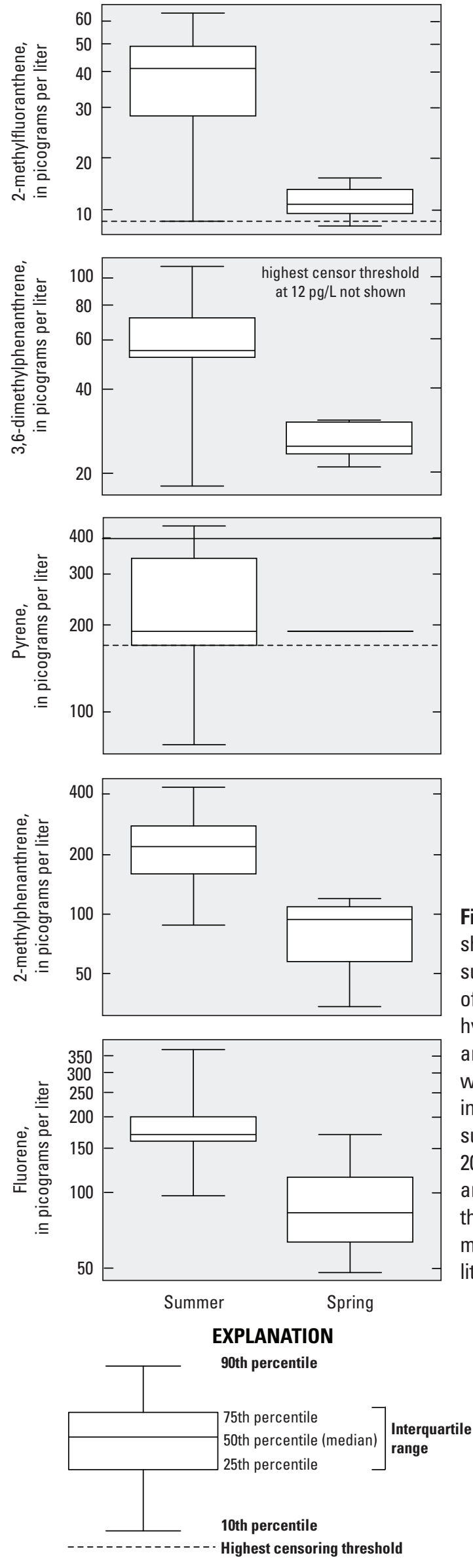

Figure 10. Boxplot graphs showing spring versus summer concentrations of polycyclic aromatic hydrocarbons for polycyclic aromatic hydrocarbons with significant differences in concentration between summer and spring samples, 2016-17. [Dashed lines are highest censoring thresholds; concentrations measured in picograms per liter $(\mathrm{pg} / \mathrm{L})]$ 
identified compounds contributing to the NMDS ordination patterns for the 2016-17 samples (table 4; fig. 9). Significantly higher concentrations of 2-methylphenanthrene and 2-methylfluoranthene contribute to the overall differences observed in the spring and summer sample patterns. Antelope Point Marina summer samples were unique - plotting farthest away from other samples - with the highest number of detections as well as the highest concentrations of those detections (fig. 9). Many PAHs separate the summer 2016 Antelope Point Marina samples (table 4), but an important PAH that separates them is naphthalene. It should be noted, however, that the detection level for the summer 2016 naphthalene samples was two orders of magnitude lower than the detection levels for the spring 2017 and summer 2017 samples (table 2; fig. 5); the spatial separation on the NMDS analysis is most likely a function of the laboratory detection level. Antelope Point Marina and Wahweap Marina spring 2017 samples also plotted distinctly from other samples; 13 different PAHs could equally

Table 4. The linkage trees and similarity profile (SIMPROF) multivariate analysis results listing compound and concentration results for significant groups shown in figure 9 .

[all groups are significant at a probability value of less than 0.001 using SIMPROF]

\begin{tabular}{|c|c|c|c|}
\hline $\begin{array}{l}\text { Clasification group split } \\
\text { (fig. 9) }\end{array}$ & Polycyclic Aromatic Hydrocarbon & $\begin{array}{l}\text { Concentration threshold for } \\
\text { summer, in picograms per liter }\end{array}$ & $\begin{array}{l}\text { Concentration threshold for } \\
\text { spring, in picograms per liter }\end{array}$ \\
\hline Group 1 & Fluorene & $>370$ & -- \\
\hline Group 1 & 2-methylnaphthalene & $>3,600$ & -- \\
\hline Group 1 & 1,2-dimethylnaphthalene & $>290$ & -- \\
\hline Group 1 & Acenaphthylene & $>340$ & -- \\
\hline Group 1 & Biphenyl & $>330$ & -- \\
\hline Group 1 & 1-methylnaphthalene & $>2,400$ & -- \\
\hline Group 1 & Naphthalene & $>2,900$ & -- \\
\hline Group 1 & Phenanthrene & $>1,200$ & -- \\
\hline Group 1 & 2,3,5-trimethylnaphthalene & $>260$ & -- \\
\hline Group 1 & 2-methylphenanthrene & $>440$ & -- \\
\hline Group 1 & 1-methylfluorene & $>320$ & -- \\
\hline Group 1 & Indeno $[1,2,3-c, d]$ pyrene & $>36$ & -- \\
\hline Group 1 & 1-ethylnaphthalene & $>220$ & -- \\
\hline Group 1 & 3,6-dimethylphenanthrene & $>110$ & -- \\
\hline Group 1 & Chrysene & $>93$ & -- \\
\hline Group 1 and 2 & 2-methylphenanthrene & $\geq 220$ & $\leq 180$ \\
\hline Group 1 and 2 & 2-methylfluoranthene & $\geq 41$ & $\leq 39$ \\
\hline Group 1 and 2 & 3,6-dimethylphenanthrene & $\geq 55$ & $\leq 53$ \\
\hline Group 1 and 2 & Chrysene & $\geq 66$ & $\leq 65$ \\
\hline Group 2 and 3-4 & 2-methylphenanthrene & $\geq 150$ & $\leq 120$ \\
\hline Group 2 and 3-4 & 2-methylfluoranthene & $\geq 19$ & $\leq 17$ \\
\hline Group 3 and 4 & Anthracene & $\geq 72$ & $\leq 48$ \\
\hline Group 3 and 4 & 1,2-dimethylnaphthalene & $\geq 180$ & $\leq 120$ \\
\hline Group 3 and 4 & 1-ethylnaphthalene & $\geq 170$ & $\leq 120$ \\
\hline Group 3 and 4 & Acenaphthylene & $\geq 200$ & $\leq 140$ \\
\hline Group 3 and 4 & 1-methylfluorene & $\geq 140$ & $\leq 75$ \\
\hline Group 3 and 4 & 1-methylnaphthalene & $\geq 1,200$ & $\leq 850$ \\
\hline Group 3 and 4 & 2-methylnaphthalene & $\geq 1,900$ & $\leq 1,500$ \\
\hline Group 3 and 4 & Phenanthrene & $\geq 460$ & $\leq 310$ \\
\hline Group 3 and 4 & Fluorene & $\geq 130$ & $\leq 100$ \\
\hline Group 3 and 4 & 2,3,5-trimethylnaphthalene & $\geq 100$ & $\leq 76$ \\
\hline Group 3 and 4 & 2-methylphenanthrene & $\geq 120$ & $\leq 98$ \\
\hline Group 3 and 4 & Fluoranthene & $\geq 270$ & $\leq 250$ \\
\hline Group 3 and 4 & 2-methylfluoranthene & $\geq 16$ & $\leq 15$ \\
\hline
\end{tabular}


define the division between Antelope Point Marina and Wahweap Marina and the other spring 2017 samples.

Twenty-two PAHs sampled for during this study were also sampled for in summer 2010 at the same sites by Schonauer and others (2013); data from the summer 2010 samples was compared to data from the summer 2016 and 2017 samples. It is important to note that Schonauer and others (2013) used SPMDs constructed and processed by a different source and used a different analytical laboratory than this study. Much of the 2010 data was censored at concentrations higher than the 2016-17 laboratory MDLs because of laboratory contamination issues in the 2010 data (table 5; Schonauer and others, 2013). Eleven PAHs, detected in the summer 2010 sampling, were also detected in the summer 2016 and summer 2017 sampling events; one PAH was detected in both the summer 2010 and summer 2017 samplings, but not in the summer 2016 sampling event; 2 PAHs were detected in 2010 but not in 2016 or 2017; and 6 PAHs were detected in both or either 2016 and 2017 but not in 2010 (fig. 11; table 5). Some of the PAH concentrations detected in 2010 may not have been reported because of the high censoring levels, but concentrations of the PAHs detected during the three sampling events are relatively similar (fig. 11). Similar to the 2016-17 data, in terms of the median rank of all the ranked concentrations detected at each site for each sampling event, PAH concentrations in summer 2010 were relatively high at Wahweap Marina, and relatively low at Dangling Rope Marina (fig. 12). PAH concentrations in summer 2010 were relatively low at Antelope Point Marina, which is very different from the 2016 and 2017 concentrations (fig. 12). Statistical analysis was completed based on 11 PAHs that were detected in summer 2010, 2016, and 2017 samples and 1 PAH detected in 2010 and 2017 samples (table 4). A pair-wise test (differences between similarity matrices) indicates that the summer 2010

Table 5. Method detection limits and number of detections of summer 2010, summer 2016, and summer 2017 samples.

[Polycyclic aromatic hydrocarbons in bold were included in the statistical analysis; $n$, number of samples]

\begin{tabular}{|c|c|c|c|c|c|c|}
\hline \multirow[t]{2}{*}{ Polycyclic aromatic hydrocarbon } & \multicolumn{3}{|c|}{ Method detection limit } & \multicolumn{3}{|c|}{ Number of detections } \\
\hline & $\begin{array}{c}\text { Summer } \\
2010\end{array}$ & $\begin{array}{c}\text { Summer } \\
2016\end{array}$ & $\begin{array}{c}\text { Summer } \\
2017\end{array}$ & $\begin{array}{l}\text { Summer } 2010 \\
\qquad(n=7)\end{array}$ & $\begin{array}{l}\text { Summer } 2016 \\
\qquad(n=7)\end{array}$ & $\begin{array}{l}\text { Summer } 2017 \\
\qquad(n=6)\end{array}$ \\
\hline Naphthalene & 33,000 & 140 & 27,000 & 0 & 7 & 0 \\
\hline Acenaphthylene & 212 & 28 & 28 & 6 & 7 & 6 \\
\hline Acenaphthene & 359 & 21 & 130 & 4 & 0 & 0 \\
\hline Fluorene & 442 & 16 & 16 & 6 & 7 & 6 \\
\hline Phenanthrene & 1,833 & 130 & 28 & 5 & 7 & 6 \\
\hline Anthracene & 320 & 15 & 13 & 6 & 7 & 6 \\
\hline Fluoranthene & 235 & 33 & 14 & 7 & 7 & 6 \\
\hline Pyrene & 730 & 15 & 15 & 4 & 7 & 6 \\
\hline Benz $[a]$ anthracene & 93 & 15 & 6.7 & 3 & 4 & 6 \\
\hline Chrysene & 62 & 29 & 6.6 & 7 & 7 & 6 \\
\hline Benzo $[b]$ fluoranthene & 50 & 32 & 6.6 & 6 & 0 & 6 \\
\hline Benzo $[k]$ fluoranthene & 95 & 31 & 7.3 & 6 & 2 & 6 \\
\hline Benzo $[a]$ pyrene & 15 & 21 & 7.7 & 0 & 0 & 0 \\
\hline Indeno $[1,2,3-c, d]$ pyrene & 92 & 31 & 9.4 & 0 & 1 & 6 \\
\hline Dibenz $[a, h]$ anthracene & 110 & 26 & 8.3 & 0 & 0 & 2 \\
\hline Benzo $[g, h, i]$ perylene & 180 & 38 & 10 & 0 & 0 & 6 \\
\hline Benzo $[b]$ thiophene & 800 & 530 & 530 & 0 & 0 & 2 \\
\hline 1,2-dimethylnaphthalene & 250 & 20 & 20 & 4 & 7 & 6 \\
\hline 1-methylfluorene & 55 & 7.9 & 8.1 & 7 & 7 & 6 \\
\hline Dibenzothiophene & 180 & 16 & 16 & 3 & 0 & 0 \\
\hline Benzo $[e]$ pyrene & 180 & 49 & 7.9 & 0 & 0 & 6 \\
\hline Perylene & 98 & 15 & 7.1 & 0 & 0 & 0 \\
\hline
\end{tabular}




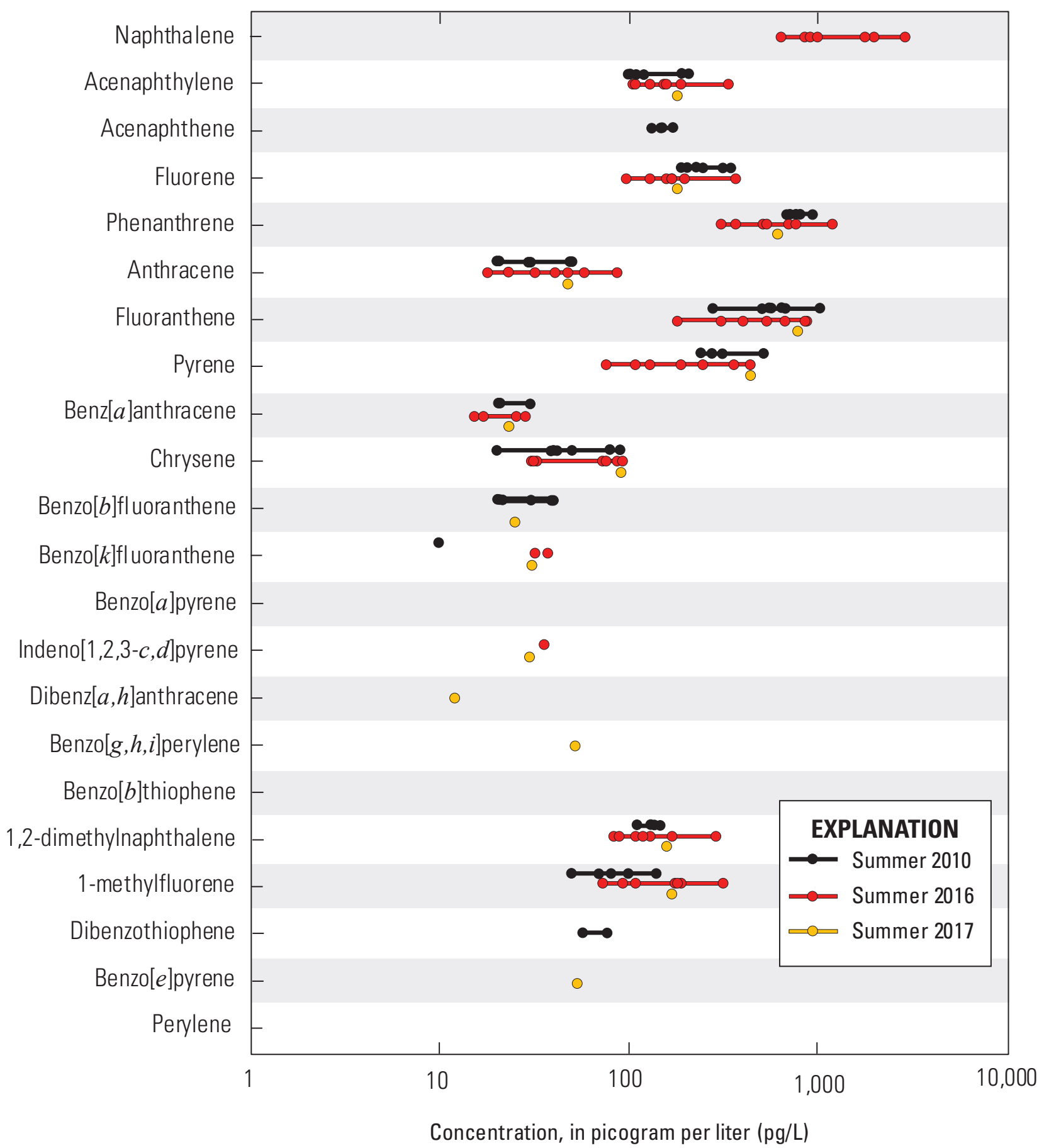

Figure 11. Diagram of polycyclic aromatic hydrocarbon concentrations at Lake Powell monitoring sites, summer 2010, summer 2016, and summer 2017. 


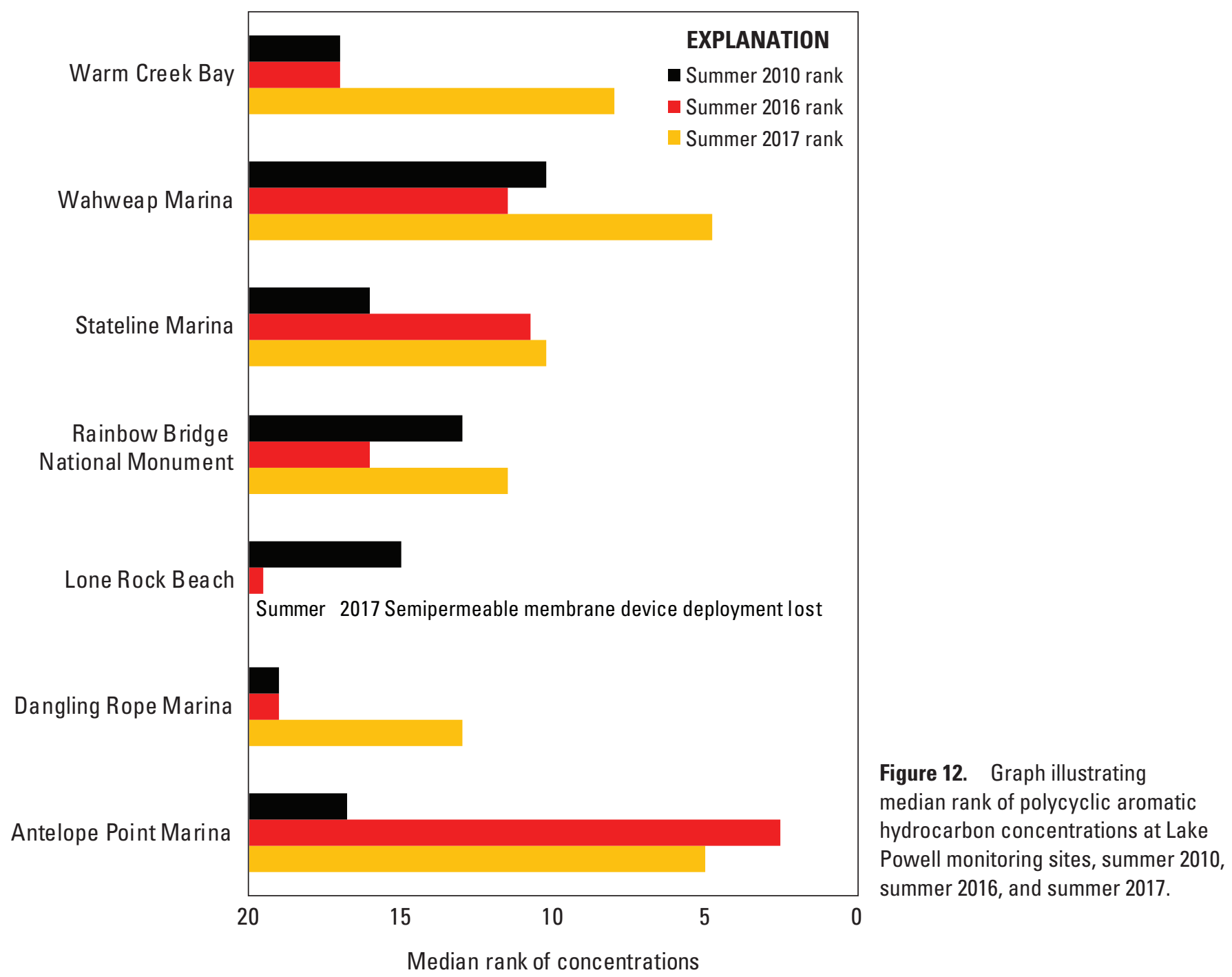

sample is not strongly different than the summer 2016 or summer 2017 samples (ANOSIM test, summer 2010 to summer 2016 and summer 2010 to summer 2017, $\mathrm{p}=0.037$ and 0.056 , respectively). This is corroborated by a NMDS multivariate analysis, which was used to analyze patterns between locations both spatially and temporally (fig. 13). In the NMDS, samples are represented by a single data point but incorporate all PAH concentrations quantified for that sample (that is, via the similarity matrix). The summer 2010, summer 2016, and summer 2017 samples show a general clustering, without a spatial separation between time periods.

\section{Discussion}

PAHs are, for the most part, extremely hydrophobic, and rapidly partition out of the aqueous phase; therefore, the consistent presence of a wide range of PAHs in the water of Lake Powell in 2016-17 suggests a chronic and (or) recent anthropogenic source. The PAHs detected in the water of Lake Powell were at low concentrations but were at concentrations similar to other large lakes in the United States that have high boat use (Lico and Johnson, 2007; Rosen and others, 2010; Alvarez and others, 2012; Ruge and others, 2015). The Environmental Protection Agency has recommended criteria for 12 of the sampled PAHs that represent concentrations in a water body below which there are no expected adverse effects to human health (table 5; Environmental Protection Agency, 2015). The Arizona Department of Environmental Quality (ADEQ) has state regulations for 13 of the sampled PAHs to protect surface-water bodies from pollution according to beneficial uses; the beneficial uses of drinking water, fish consumption, full body contact, and aquatic and wildlife uses for cold water are designated for Lake Powell and have PAH standards (table 5; Arizona Department of Environmental Quality, 2009). All of the PAH concentrations in the 2016-17 samples were orders of magnitude lower than Environmental Protection Agency criteria or ADEQ standards.

Samples collected in 2016-17 at Antelope Point Marina and Wahweap Marina, followed by Stateline Marina, generally contained the highest number of detections of PAHs at the highest concentrations. PAH concentrations in samples 


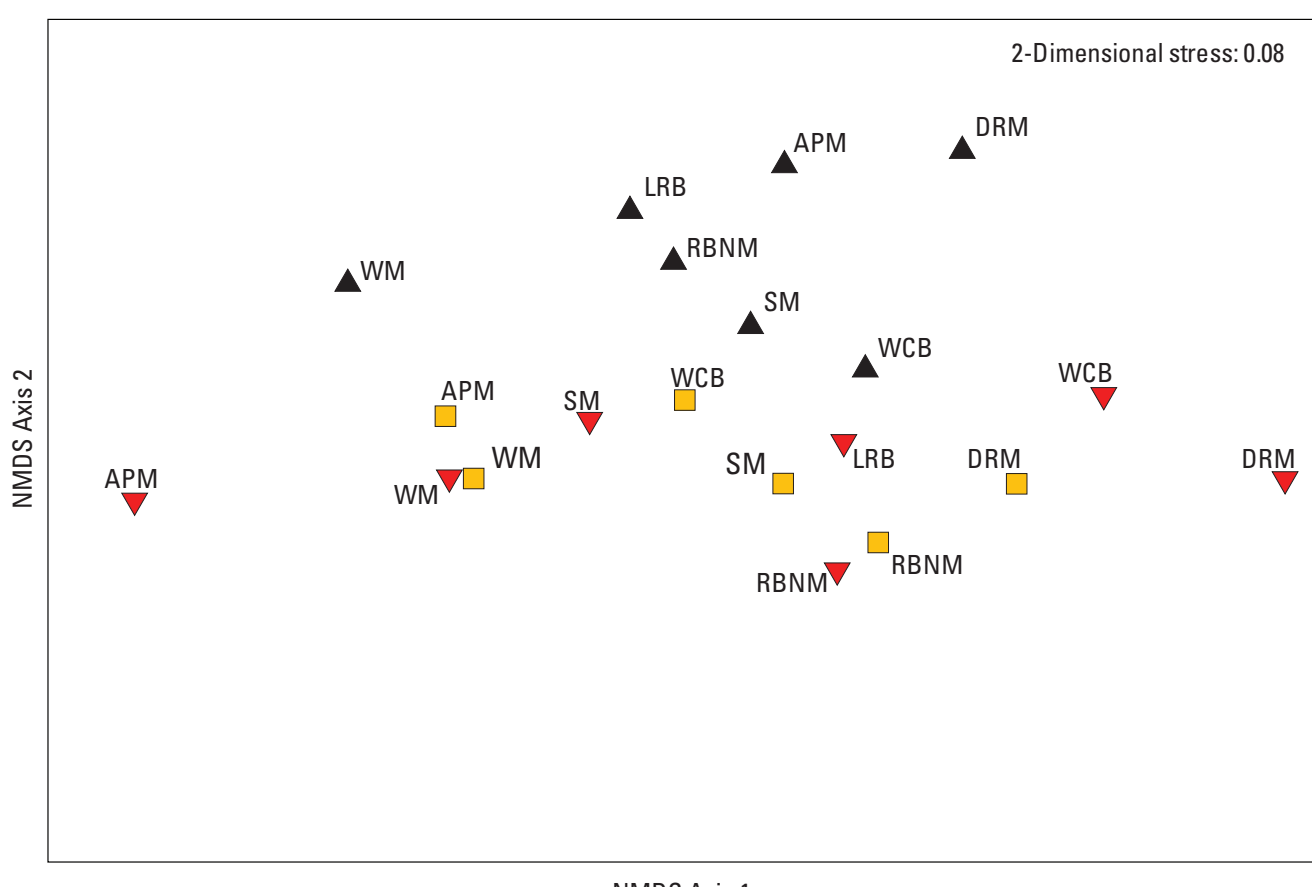

\section{EXPLANATION}

SM Stateline Marina

WM Wahweap Marina

WCB Warm Creek Bay

APM Antelope Point Marina

DRM Dangling Rope Marina

LRB Lone Rock Beach

RBNM Rainbow Bridge

National Monument

- Summer 2010

- Summer 2016

$\square \quad$ Summer 2017

NMDS Axis 1

Figure 13. Diagram of a non-metric multidimensional scaling ordination for polycyclic aromatic hydrocarbon concentrations at each site during each summer sampling event, summer 2010, summer 2016, and summer 2017.

Table 6. National recommended human health criteria and Arizona surface-water quality standards for polycyclic aromatic hydrocarbons.

[EPA, Environmental Protection Agency; ADEQ, Arizona Department of Environmental Quality; pg/L, picograms per liter; NA, not applicable\}

\begin{tabular}{|c|c|c|c|c|c|c|c|}
\hline $\begin{array}{l}\text { Polycyclic aromatic } \\
\text { hydrocarbon }\end{array}$ & $\begin{array}{l}\text { Maximum } \\
\text { concentration in } \\
2016-17, \mathrm{pg} / \mathrm{L}\end{array}$ & $\begin{array}{l}\text { EPA human } \\
\text { health criteria for } \\
\text { the consumption } \\
\text { of water plus } \\
\text { organism', pg/L }\end{array}$ & $\begin{array}{l}\text { EPA human } \\
\text { health cri- } \\
\text { teria for the } \\
\text { consumption } \\
\text { of organism } \\
\text { only } 1, \mathrm{pg} / \mathrm{L}\end{array}$ & $\begin{array}{l}\text { ADE0 drink- } \\
\text { ing water } \\
\text { standard }{ }^{2} \\
\text { pg/L }\end{array}$ & $\begin{array}{l}\text { ADEO fish } \\
\text { consump- } \\
\text { tion stan- } \\
\text { dard }^{2}, \mathrm{pg} / \mathrm{L}\end{array}$ & $\begin{array}{l}\text { ADEQ full } \\
\text { body contact } \\
\text { standard } \\
\text { pg/L }\end{array}$ & $\begin{array}{c}\text { ADEO } \\
\text { aquatic and } \\
\text { wildlife } \\
\text { standard, } \\
\text { cold water, } \\
\text { chronic }^{2} \text {, } \\
\text { pg/L }\end{array}$ \\
\hline Acenaphthene & $<130$ & $7 \times 10^{7}$ & $9 \times 10^{7}$ & $4.2 \times 10^{8}$ & $1.98 \times 10^{8}$ & $5.6 \times 10^{10}$ & $5.5 \times 10^{8}$ \\
\hline Anthracene & 94 & $3 \times 10^{8}$ & $4 \times 10^{8}$ & $2.1 \times 10^{9}$ & $7.4 \times 10^{7}$ & $2.8 \times 10^{11}$ & NA \\
\hline $\operatorname{Benzo}[a]$ anthracene & 28 & 1,200 & 1,300 & 5,000 & 20,000 & $2 \times 10^{5}$ & NA \\
\hline Benzo $[a]$ pyrene & $<40$ & 120 & 130 & $2 \times 10^{5}$ & 20,000 & $2 \times 10^{5}$ & NA \\
\hline Benzo $[b]$ fluoranthene & 25 & 1,200 & 1,300 & NA & NA & NA & NA \\
\hline Benzo $[k]$ fluoranthene & 38 & 12,000 & 13,000 & 5,000 & 20,000 & $1.9 \times 10^{6}$ & NA \\
\hline Chrysene & 93 & $1.2 \times 10^{5}$ & $1.3 \times 10^{5}$ & 5,000 & 20,000 & $1.9 \times 10^{7}$ & NA \\
\hline Dibenzo $[a, h]$ anthracene & 12 & 120 & 130 & 5,000 & 20,000 & $1.9 \times 10^{6}$ & NA \\
\hline Fluoranthene & 870 & $2 \times 10^{7}$ & $2 \times 10^{7}$ & $2.8 \times 10^{8}$ & $2.8 \times 10^{7}$ & $3.7333 \times 10^{10}$ & NA \\
\hline Fluorene & 370 & $5 \times 10^{7}$ & $7 \times 10^{7}$ & $2.8 \times 10^{8}$ & $1.067 \times 10^{9}$ & $3.7333 \times 10^{10}$ & NA \\
\hline Ideno $[1,2,3-c, d]$ pyrene & 36 & 1,200 & 1,300 & 50,000 & $2 \times 10^{5}$ & $1.9 \times 10^{6}$ & NA \\
\hline Naphthalene & 2,900 & NA & $\mathrm{NA}$ & $1.4 \times 10^{8}$ & $1.524 \times 10^{9}$ & $1.8667 \times 10^{10}$ & $2.1 \times 10^{8}$ \\
\hline Phenanthrene & 1,200 & NA & NA & NA & NA & NA & $6.3 \times 10^{6}$ \\
\hline Pyrene & 440 & $2 \times 10^{7}$ & $3 \times 10^{7}$ & $2.1 \times 10^{8}$ & $8 \times 10^{8}$ & $2.8 \times 10^{10}$ & NA \\
\hline
\end{tabular}

${ }^{1}$ U.S. Environmental Protection Agency, 2015

${ }^{2}$ Arizona Department of Environmental Quality, 2009 
collected at Dangling Rope Marina generally contained the lowest number of detections at relatively low concentrations. Antelope Point Marina, Wahweap Marina, and Stateline Marina are close to one another, and are the most downstream sampling locations on the main channel of Lake Powell prior to Glen Canyon Dam. Antelope Point Marina and Wahweap Marina are the sites with the highest watercraft traffic, with boat fueling docks, long-term boat moorings and boat rentals; Stateline Marina also has long-term boat moorings (Hart and others, 2012). Dangling Rope Marina is the farthest upstream sampling location on the main channel of the lake. Though Dangling Rope Marina has boat-fueling docks, it has less boat traffic and fewer boat slips than Antelope Point or Wahweap Marinas, and has only short-term moorings (Hart and others, 2012).

PAH concentrations in spring 2017 samples were significantly different than the summer 2016 and summer 2017 samples. More PAHs were detected during summer sampling than were detected during spring sampling, and PAHs detected during the summer were generally at higher concentrations than during the spring. Water-surface elevations in Lake Powell were 7 to 36 feet higher, and water temperatures at the sampling depths were generally 5 to 10 degrees Celsius warmer, during summer sampling than spring sampling. The difference in water-surface elevation would not be expected to affect PAH concentrations in the water. Differences in water temperature can affect the uptake rate of PAHs into SPMDs (Huckins and others, 2006); this effect, however, was accounted for by the PRCs in each SPMD during deployment. In addition, minor differences in water temperatures would not be expected to affect PAH concentrations in the water. Boat use during the summer sampling events was much higher than during the spring sampling event, with about 2,800 more boat rentals at Wahweap Marina during either summer 2016 or summer 2017 sampling than during spring 2017 sampling, and about the same number of boat moorings. Because PAHs generally have a low solubility in water, their frequent presence during the summer months is most likely related to high boat traffic relative to low boat traffic during the spring months. This is likely the most important factor controlling the seasonality of PAH concentrations in Lake Powell.

Concentrations for 12 PAHs detected in summer 2010 samples were not significantly different than concentrations of the same 12 PAHs in summer 2016 and summer 2017. Similar to summer 2016-17, however, the samples collected in summer 2010 at Wahweap Marina and Stateline Marina contained relatively higher PAH concentrations than the other sites. The sample collected at Antelope Point Marina in summer 2010, however, contained lower PAH concentrations than most of the other sites, and was relatively much lower than the summer 2016-17 concentrations. Antelope Point Marina is the newest marina on Lake Powell, coming into service in 2005 (Hart and others, 2012); the relative increase in PAH concentrations at Antelope Point Marina between summer 2010 and summer 2016-17 may be related to this site changing over from a site without a marina to a full-service marina during that time period.
During the summer 2010 sampling, water-surface elevations in Lake Powell were 21 to 44 feet higher than during the summer 2016 or summer 2017 sampling events, and water temperatures at the sampling depths were generally the same during the two events (Schonauer and others, 2013). These differences, in water-surface elevation and minor differences in water temperatures, would not be expected to affect PAH concentrations in the water. Boat use during summer 2010 sampling was about the same as during the summer 2016 and summer 2017 samplings, with just 103 and 14 more average monthly boat rentals at Wahweap Marina during the summer 2010 sampling than during either the summer 2016 or summer 2017 sampling, respectively. Slightly more boat moorings were occupied during the summer 2010 sampling event than during the summer 2016 or summer 2017 sampling events, with 104 to 130 more average monthly boat moorings occupied at Wahweap Marina during the summer 2010 sampling than during either the summer 2016 or summer 2017 sampling, respectively. Though boat use during the summer 2010, 2016, and 2017 sampling was relatively consistent, special regulations concerning lower emission standards of personal watercraft have been in place since December 31, 2012. These regulations were enacted in part to manage and lower PAH concentrations in Lake Powell. Concentrations of the 12 PAHs detected in summer 2010, however, were not significantly different between the summer of 2010 and the summers of 2016 and 2017. The similar concentrations of PAHs in both the 2010 samples and the 2016-17 samples, coupled with the similar amount of boat use between the two time periods, suggests that the regulations defining emission standards for personal watercraft have not affected PAH concentrations in Lake Powell.

\section{Summary}

Polycyclic aromatic hydrocarbon contamination related to boat use is one of the most important water-quality issues affecting Lake Powell within Glen Canyon National Recreation Area. High concentrations of PAHs in water are common around marinas and other areas with extensive motorboat activity because of uncombusted or partially combusted releases of oil and gasoline from boat engines. The fate of these compounds in Lake Powell is of serious environmental concern because of their toxicity, carcinogenicity, and their moderate persistence once they enter the ecosystem. In an effort to reduce PAH concentrations in Lake Powell, the NPS adopted special regulations in 2003, effective December 31, 2012 , to manage the emission standards of personal watercraft on the lake.

In 2016-17, the U.S. Geological Survey assessed the presence and concentrations of PAHs in Lake Powell at seven sites where concentrations have historically been elevated, and one site where concentrations have historically been relatively low. One-month, time-composite samples were collected from the epilimnion of the lake at each sampling site using SPMDs 
during two periods of relatively high boat use (summer), and one period of relatively low boat use (spring). The results from this study provides Glen Canyon National Recreation Area with the necessary information to determine if the current policies concerning personal watercraft on Lake Powell are effective management techniques for lowering PAH concentrations.

Twenty-eight out of 33 PAHs analyzed were detected in Lake Powell during the 3 sampling events. PAH concentrations in the two summer sampling events were significantly different than the spring sampling event. During the two summer sampling events, PAH concentrations were higher, and more compounds were detected, than during the spring sampling event; concentrations of 10 compounds were significantly higher in the summer samples than in the spring samples. Twenty-two of the PAHs analyzed in 2016-17 had previously been analyzed by the USGS in summer 2010 at the same sites using the same collection method. Eleven of 22 compounds were detected in the summer 2010, summer 2016, and summer 2017 sampling events, and 1 was detected in the summer 2010 and summer 2017 samplings, but not in the summer 2016 sampling event. PAH concentrations were not significantly different between the summer 2010, 2016, and summer 2017 sampling events. PAH concentrations from the 2016-17 samples were generally higher, and more PAHs were detected, at Antelope Point Marina, Wahweap Marina, and Stateline Marina, which are high-use marinas located the farthest downstream on the lake. PAH concentrations from the 2010 samples were also generally higher at Wahweap Marina.

Because PAHs generally have a low solubility in water and do not remain in the water column long after exposure, the consistency in PAH types and concentrations, as well as spatial distribution, between past and present conditions indicates that PAHs are chronically introduced into Lake Powell by activities associated with boat use. The higher concentrations and greater number of detections of PAHs during the summer months than the spring months is most likely related to high boat use during the summer relative to the spring. Similarly, the higher concentrations and greater number of detections of PAHs at relatively high-use marinas is most likely related to long-term boat moorings at these marinas and higher boat traffic compared to the other sampled sites. The similar concentrations of PAHs in both the summer 2010 samples and the summer 2016 and summer 2017 samples, coupled with the similar volume of boat use between the two time periods, suggests that the regulations enacted in December 31, 2012, defining emission standards for personal watercraft have not affected $\mathrm{PAH}$ concentrations in Lake Powell.

\section{References Cited}

Abrajano Jr., T.A., Yan, B., Song, J., Bopp, R., O’Malley, V., 2003, High-molecular-weight petrogenic and pyrogenic hydrocarbons in aquatic environments, chap. 13 of Heinrich, H.D. and Turekian, K.K., eds., Treatise on Geochemistry: Amsterdam, Elsevier Science, v. 9, 50 p.

Alvarez, D.A., Cranor, W.L., Perkins, S.D., Clark, R.C., and Smith, S.B., 2008, Chemical and toxicological assessment of organic contaminants in surface waters using passive samplers: Journal of Environmental Quality, v. 37, p. 1,024-1,033.

Alvarez, D.A., 2010, Guidelines for the use of the semipermeable membrane device (SPMD) and the polar organic chemical integrative sampler (POCIS) in environmental monitoring studies: U.S. Geological Survey Techniques and Methods 1-D4, 28 p., http://pubs.usgs.gov/tm/tm1d4/.

Alvarez, D.A., Rosen, M.R., Perkins, S.D., Cranor, W.L., Schroeder, V.L., and Jones-Lepp, T.L., 2012, Bottom sediment as a source of organic contaminants in Lake Mead, Nevada, USA: Chemosphere, v. 88, no. 5, p. 605-611.

Annan, S. Y., Liu, P., and Zhang, Y., 2009, Comparison of the Kaplan-Meier, Maximum Likelihood, and ROS Estimators for left-censored data using simulation studies, 9 p. accessed July 20, 2018, at http://citeseerx.ist.psu.edu/viewdoc/downlo ad?doi=10.1.1.211.1833\&rep=rep1\&type $=$ pdf.

Arizona Department of Environmental Quality, 2009, Department of Environmental Quality water quality standards - Water quality standards for surface waters: Arizona Department of State Office of the Secretary of State, Public Services Division, 65 p. accessed August 8, 2018, at https:// legacy.azdeq.gov/environ/water/standards/download/SWQ Standards-1-09-unofficial.pdf.

Bureau of Reclamation, 2018, Water operations-Historic Data, Lake Powell: Bureau of Reclamation, accessed July 24, 2018, at https:/www.usbr.gov/rsvrWater/HistoricalApp. html.

Clarke, K.R., and Gorley, R.N., 2006, Primer v6-User manual/tutorial: Plymouth, United Kingdom, PRIMER-E, Ltd., 190 p.

Clarke, R.K, Somerfield, P.J., and Gorley, R.N., 2008, Testing of null hypotheses in exploratory community analysessimilarity profiles and biota-environment linkage: Journal of Experimental Marine Biology and Ecology, v. 366, no.1-2, p. 56-69, https://doi.org/10.1016/j.jembe.2008.07.009. 
Environmental Protection Agency, 2010, Method 1664, Revision B-n-Hexane Extractable Material (HEM; Oil and Grease) and Silica Gel Treated n-Hexane Extractable Material (SGT-HEM; Non-polar Material) by extraction and gravimetry: U.S. Environmental Protection Agency, EPA821-R-10-001, 30 p., https://www.epa.gov/sites/production/ files/2015-08/documents/method_1664b_2010.pdf.

Environmental Protection Agency, 2015, National recommendation water quality criteria-Human health criteria table: U.S. Environmental Protection Agency, accessed August 16, 2018, at https://www.epa.gov/wqc/national-recommendedwater-quality-criteria-human-health-criteria-table.

Hart, R.J., and Sherman, K.M., 1996, Physical and chemical characteristics of Lake Powell at the forebay and outflows of Glen Canyon Dam, northeastern Arizona, 1990-91: U.S. Geological Survey Water-Resources Investigations Report 96-4016, 78 p., https://pubs.usgs.gov/wri/1996/4016/report. pdf.

Hart, R.J., Taylor, H.E., and Anderson, G.M., 2012, Establishment of sentinel sampling sites to monitor changes in water and sediment quality and biota related to visitor use at Lake Powell, Arizona and Utah, 2004-2006: U.S. Geological Survey Open-File Report 2012-1237, 25 p. https://pubs. usgs.gov/of/2012/1237/.

Helsel, D., and Lee, L.R., 2006, Analysis of environmental data with nondetects; statistical methods for censored environmental data in Continuing education courses at the Joint Statistical Meetings: Seattle, Wash., American Statistical Association, August 6-10.

Huckins, J.N., Petty, J.D., Booij, K., 2006, Monitors of organic chemicals in the environment-semipermeable membrane devices: New York, Springer, 223 p.

Keith, L., 1991, Environmental sampling and analysis: a practical guide: Boca Raton, Fl, CRC Press, 143 p.

Lee, L., 2015, Package 'NADA', Nondetects and data analysis for environmental data, version 1.5-6: The Comprehensive R Archive Network web page, accessed May 21, 2018, at https://cran.r-project.org/web/packages/NADA/NADA.pdf.

Lico, M.S., and Johnson, B.T., 2007, Gasoline-related compounds in Lakes Mead and Mohave, Nevada, 2004-06: U.S. Geological Survey Scientific Investigations Report 2007-5144, 28 p.

Marzooghi, S., and Di Toro, D.M., 2017, A critical review of polycyclic aromatic hydrocarbon phototoxicity models: Environmental Toxicology and Chemistry, v. 36, p. 11381148.

Mayo, J.P., Coes, A.L., Paretti, N.V., Macy, J.P., Alvarez, D.A., 2018, Supplemental Continuous Temperature Data, Temperature Profile Data, SPMD Environmental Concentration Data and SPMD Quality-control Data for the Assessment of Hydrocarbon Concentrations in Southern Lake Powell (2016-2017): U.S. Geological Survey data release, https:// doi.org/10.5066/P96QGCVN.
National Park Service, 2003, Final environmental impact statement_-personal watercraft rulemaking; Glen Canyon National Recreation Area, Arizona and Utah: U.S. Department of Interior, National Park Service, v.1, 426 p., at http:// azmemory.azlibrary.gov/digital/collection/feddocs/id/1072

National Park Service, 2004, A monitoring plan for the occurrence of hydrocarbon constituents in Lakes Powell, Mean, and Mohave-Arizona, Nevada, and Utah: National Park Service, 34 p., https://archive.org/details/monitoringplanfo00nati.

National Park Service, 2018, Glen Canyon National Recreation Area-Annual park recreation visitation (1904-last calendar year): National Park Service, accessed DATE, at https://irma.nps.gov/Stats/SSRSReports/Park\%20Specific\%20Reports/Annual\%20Park\%20Recreation \%20 Visitation\%20(1904\%20-\%20Last\%20Calendar\%20 Year)?Park=GLCA.

National Park Service, 2010, Glen Canyon National Recreation Area, 36 C.F.R $\$ 7.70$ (e)(3): National Park Service, 2 p., accessed June 26, 2018, at https:/www.nps.gov/romo/ learn/management/upload/CFR-2010-title36-vol1-chapI.pdf

Rosen, M.R., Alvarez, D.A., Goodbred, S.L., Leiker, T.J., and Patiño, R., 2010, Sources and distribution of organic compounds using passive samplers in Lake Mead National Recreation Area, Nevada and Arizona, and their implications for potential effects on aquatic biota: Journal of Environmental Quality, v. 39, p. 1161-1172.

Ruge, Z., Muir, D., Helm, P., and Lohman, R., 2015, Concentrations, trends, and air-water exchange of PAHs and PBDEs derived from passive samplers in Lake Superior in 2011: Environmental Science and Technology, v. 49, p. 13777-13786.

Schonauer, K.T., Hart, R.J., and Antweiler, R.C., 2013, The presence and distribution of polycyclic aromatic hydrocarbons and inorganic elements in water and lakebed materials and the potential for bioconcentration in biota at established sampling sites on Lake Powell, Utah and Arizona: U.S. Geological Survey Open-File Report 2013-1299, 27 p., https://dx.doi.org/10.3133/ofr20131299.

U.S. Congress, 1972, An act to establish the Glen Canyon National Recreation Area in the states of Arizona and Utah: U.S. Congress Public Law 92-593, 3 p., accessed June 26, 2018, at http://uscode.house.gov/statviewer. $\mathrm{htm}$ ? volume $=86 \&$ page $=1311$.

U.S. Geological Survey, 2018, USGS water data for the nation: U.S. Geological Survey National Water Information System database, accessed May 25, 2018, at https://doi. org/10.5066/F7P55KJN.

U.S. National Library of Medicine, 2017, Toxicology Data Network-Hazardous Substances Data Bank: National Institutes of Health, accessed October 11, 2017, at https:// toxnet.nlm.nih.gov/newtoxnet/hsdb.htm. 
Menlo Park Publishing Service Center California

Manuscript approved for publication June 26, 2019

Edited by Phil A. Frederick

Layout and design by Kimber Petersen 


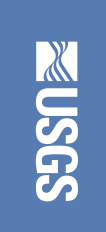

ISSN 2328-0328 (online)

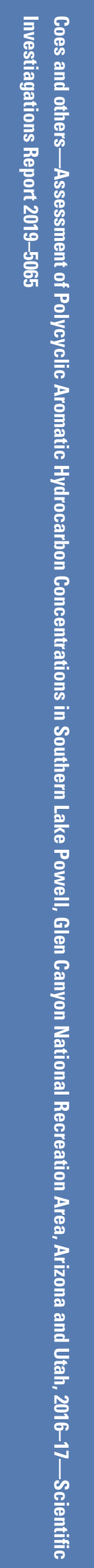

思

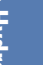

